\title{
Spectral optical properties of long-range transport Asian dust and pollution aerosols over Northeast Asia in 2007 and 2008
}

\author{
J. Jung ${ }^{1, *}$, Y. J. Kim ${ }^{1}$, K. Y. Lee ${ }^{1}$, M. G.-Cayetano ${ }^{1}$, T. Batmunkh ${ }^{1}$, J.-H. Koo ${ }^{2, * *}$, and J. Kim ${ }^{2}$ \\ ${ }^{1}$ Advanced Environmental Monitoring Research Center (ADEMRC), Gwangju Institute of Science and Technology (GIST), \\ Gwangju 500-712, Korea \\ ${ }^{2}$ Department of Atmospheric Science, Yonsei University, Seoul 120-749, Korea \\ *now at: Institute of Low Temperature Science, Hokkaido University, Sapporo 060-0819, Japan \\ ** now at: School of Earth and Atmospheric Sciences, Georgia Institute of Technology, Atlanta, USA
}

Received: 18 November 2009 - Published in Atmos. Chem. Phys. Discuss.: 1 February 2010

Revised: 12 June 2010 - Accepted: 14 June 2010 - Published: 21 June 2010

\begin{abstract}
As a part of the IGAC (International Global Atmospheric Chemistry) Mega-cities program, aerosol physical and optical properties were continuously measured from March 2007 to March 2008 at an urban site $\left(37.57^{\circ} \mathrm{N}\right.$, $126.94^{\circ} \mathrm{E}$ ) in Seoul, Korea. Spectral optical properties of long-range transported Asian dust and pollution aerosols have been investigated based on the year long measurement data. Optically measured black carbon/thermally measured elemental carbon (BC/EC) ratio showed clear monthly variation with high values in summer and low values in winter mainly due to the enhancement of light attenuation by the internal mixing of EC. Novel approach has been suggested to retrieve the spectral light absorption coefficient $\left(b_{\text {abs }}\right)$ from Aethalometer raw data by using $\mathrm{BC} / \mathrm{EC}$ ratio. Mass absorption efficiency, $\sigma_{\mathrm{abs}}\left(=b_{\mathrm{abs}} / E C\right)$ at $550 \mathrm{~nm}$ was determined to be $9.0 \pm 1.3,8.9 \pm 1.5,9.5 \pm 2.0$, and $10.3 \pm 1.7 \mathrm{~m}^{2} \mathrm{~g}^{-1}$ in spring, summer, fall, and winter, respectively with an annual mean of $9.4 \pm 1.8 \mathrm{~m}^{2} \mathrm{~g}^{-1}$. Threshold values to classify severe haze events were suggested in this study. Increasing trend of aerosol single scattering albedo (SSA) with wavelength was observed during Asian dust events while little spectral dependence of SSA was observed during long-range transport pollution (LTP) events. Satellite aerosol optical thickness (AOT) and Hysplit air mass backward trajectory analyses as well as chemical analysis were performed to characterize the dependence of spectral optical properties on aerosol type. Results from this study can provide useful information for studies on regional air quality and aerosol's effects on climate change.
\end{abstract}

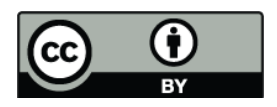

Correspondence to: Y. J. Kim (yjkim@gist.ac.kr)

\section{Introduction}

Radiative forcing (RF) is defined as "the change in net (down minus up) irradiance (solar plus long wave; in $\mathrm{W} \mathrm{m}^{-2}$ ) at the tropopause after allowing for stratospheric temperatures to readjust to radiative equilibrium, but with surface and tropospheric temperatures and state held fixed at the unperturbed values" (IPCC, 2007). The aerosol RF depends on not only their spatial distributions, but also the size, shape, and chemical composition of the particles. The aerosol RF influences on various aspects (e.g., cloud formation) of the hydrological cycles. The total direct aerosol RF, derived from models and observations, is estimated to be $-0.5 \pm 0.4$ $\mathrm{Wm}^{-2}$, with a medium-low level of scientific understanding. The estimates are: $-0.4 \pm 0.2 \mathrm{Wm}^{-2}$ (sulfate), $-0.05 \pm 0.05$ $\mathrm{Wm}^{-2}$ (fossil fuel organic carbon), $+0.2 \pm 0.15 \mathrm{Wm}^{-2}$ (fossil fuel black carbon), $+0.03 \pm 0.12 \mathrm{Wm}^{-2}$ (biomass burning), $-0.1 \pm 0.1 \mathrm{Wm}^{-2}$ (nitrate) and $-0.1 \pm 0.2 \mathrm{Wm}^{-2}$ (mineral dust) (IPCC, 2007). However, there is substantial uncertainty in the magnitude and spatial distribution of the RF by aerosols. One of the largest sources of uncertainty in estimation of the aerosol RF is the Asian aerosol. A mixture of both heavy air pollution over the Asian continent and seasonal increases of desert dust particles results in very complex optical properties of the particles (Höller et al., 2003). An expected tripling of Asian emissions from 1985 to 2010 implies that aerosols and aerosol precursor emissions will increase sharply over the next decade, which makes regular observations an urgent necessity (Jacob et al., 1999).

Radiative transfer models used to predict the aerosol RF are based on spectral optical properties calculated by MieTheory. While this is a reasonable approach for spherical

Published by Copernicus Publications on behalf of the European Geosciences Union. 
Table 1. Measurement parameters and instrument conditions used in this study.

\begin{tabular}{|c|c|c|c|}
\hline Measurement parameters & Instrument & Particle size range & Time Interval \\
\hline Organic carbon/elemental carbon (OC/EC) & $\begin{array}{l}\text { Semi-continuous OC/EC analyzer (Sunset } \\
\text { Lab., RT3015) }\end{array}$ & $D_{p}<2.5 \mu \mathrm{m}$ & $1 \mathrm{~h}$ \\
\hline Black carbon $(\mathrm{BC})$ & 7- $\lambda$ Aethalometer (Magee Scientific, AE31) & $D_{p}<2.5 \mu \mathrm{m}$ & $5 \mathrm{~min}$ \\
\hline $\begin{array}{l}\text { Light scattering coefficient }\left(b_{\text {scat }}\right) \text { of ambi- } \\
\text { ent particle }\end{array}$ & Nephelometer (Optec, NGN-2) & $D_{p}>0 \mu \mathrm{m}$ & $2 \mathrm{~min}$ \\
\hline $\begin{array}{l}\text { Light scattering coefficient }\left(b_{\text {scat }}\right) \text { of dry } \\
\mathrm{PM}_{2.5} \text { particle }\end{array}$ & Nephelometer (Optec, NGN-3a) & $D_{p}<2.5 \mu \mathrm{m}$ & $2 \min$ \\
\hline Aerosol optical thickness (AOT) & Skyradiometer (PREDE, POM-02) & $D_{p}>0 \mu \mathrm{m}$ & $10 \mathrm{~min}$ \\
\hline $\begin{array}{l}\mathrm{PM}_{10}, \mathrm{PM}_{2.5}, \mathrm{PM}_{1.0} \text { Ambient/Volatile mass } \\
\text { concentrations }\end{array}$ & Aerosol Spectrometer (Grimm, 265) & $\begin{array}{l}D_{p}<10 \mu \mathrm{m}, \quad 2.5 \mu \mathrm{m} \\
1.0 \mu \mathrm{m}\end{array}$ & $30 \mathrm{~min}$ \\
\hline PM size distribution & & $D_{p}>0.25 \mu \mathrm{m}$ & $1 \mathrm{~min}$ \\
\hline
\end{tabular}

particles like aqueous sulfate aerosol, soot particles possess a rather complex fractal-like morphology which makes a reliable modeling of their optical properties much more difficult. Moreover, the mixing state of EC in the atmospheric aerosol is usually assumed to be external, which overestimates the above net cooling effect significantly (Jacobson, 2001). Climate models typically treat EC as the only light-absorbing aerosol compounds. If spectral dependence of aerosol light absorption is underestimated in models, the aerosol positive RF will be understated (Bond, 2001). So characterization of additional aerosol absorption at short wavelength is very important for the better estimation of the aerosol RF. Heintzenberg et al. (1997) pointed out the importance of the singlescattering albedo in climate models and the essential role of accurate observational data. Concerning the wavelength dependence of the single-scattering albedo data are still very scarce (Dubovik et al., 2002; Höller et al., 2003). Spectral characteristics of aerosol light absorption and scattering are not well characterized in part due to the lack of long-term in-situ measurement over Northeast Asia.

The objective of this research is to characterize the spectral optical properties of long-range transport Asian Dust and pollution aerosols as well as urban aerosols. Seasonal pattern of spectral optical properties of urban aerosols in the measurement site has been investigated. The source regions and transport pathway of anthropogenic pollution and Asian dust have been characterized based on a satellite aerosol optical thickness (AOT) and back-trajectory analysis.

\section{Measurement and method}

As a part of the IGAC Mega-cities program, aerosol physical and optical properties were continuously measured from March 2007 to March 2008 at an urban site $\left(37.57^{\circ} \mathrm{N}\right.$, $126.94^{\circ}$ E) in Seoul, Korea (Fig. 1). Seoul has population more than 10.4 million with over 2.8 million automobiles. All instruments were was installed in a temperature con-
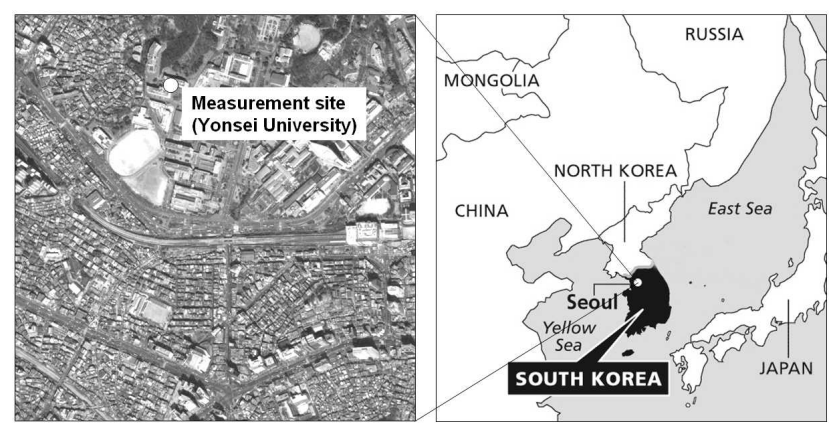

Fig. 1. Area map of the measurement site $\left(37.57^{\circ} \mathrm{N}, 126.94^{\circ} \mathrm{E}\right)$ in Seoul, Korea.

trolled trailer on the rooftop of the Science Building ( $\sim 30 \mathrm{~m}$ height) of Yonsei University, which is located in the northwest part of Seoul. Sample air was aspirated from the rooftop of the trailer to each instrument. The time represents the Korean local time (GMT+09:00) unless otherwise noted. An overview of the instrumentation is given in Table 1. All parameters in Table 1 were hourly averaged and used in this study.

\subsection{Sunset semi-continuous OC/EC analyzer and 7-wavelength aethalometer}

Particulate carbonaceous aerosol was measured using a Sunset Laboratory semi-continuous OC/EC analyzer (Sunset Lab., Model RT3015) with thermal-optical transmittance (TOT) protocol for pyrolysis correction and NIOSH (National Institute for Occupational Safety and Health) 5040 method temperature profile (Birch and Cary, 1996; Jeong et al., 2004; Kim et al., 2006). External calibration was performed monthly using known amounts of sucrose. For temporal resolution of $1 \mathrm{~h}$ (44 min of collection) measurement, the detection limit of EC was determined to be $0.01 \mu \mathrm{gC} \mathrm{m}^{-3}$, calculated as three times the standard deviation $(3 \sigma)$ of 
Table 2. Detection limit and uncertainties of the measurement parameters.

\begin{tabular}{|c|c|c|c|c|c|c|}
\hline Instrument & Parameter & Unit & Dynamic blank & $\begin{array}{l}\text { Standard devia- } \\
\text { tion }(\sigma)\end{array}$ & $\begin{array}{l}\text { Detection limit } \\
(3 \sigma)\end{array}$ & $\begin{array}{l}\text { Uncertainty } \\
(\%)\end{array}$ \\
\hline \multirow{7}{*}{$\begin{array}{l}\text { Aethalometer } \\
\text { AE31) }\end{array}$} & $\mathrm{BC}(370 \mathrm{~nm})$ & $\mu \mathrm{g} \mathrm{m}^{-3}$ & 0.105 & 0.052 & 0.156 & $10 \%$ \\
\hline & $\mathrm{BC}(470 \mathrm{~nm})$ & & 0.115 & 0.054 & 0.161 & \\
\hline & $\mathrm{BC}(520 \mathrm{~nm})$ & & 0.106 & 0.062 & 0.187 & \\
\hline & $\mathrm{BC}(590 \mathrm{~nm})$ & & 0.111 & 0.071 & 0.213 & \\
\hline & $\mathrm{BC}(660 \mathrm{~nm})$ & & 0.096 & 0.076 & 0.228 & \\
\hline & $\mathrm{BC}(880 \mathrm{~nm})$ & & 0.090 & 0.088 & 0.263 & \\
\hline & $\mathrm{BC}(950 \mathrm{~nm})$ & & 0.097 & 0.094 & 0.281 & \\
\hline \multirow{3}{*}{$\begin{array}{l}\text { Sunset OC/EC analyzer } \\
\text { (Sunset, RT3015) }\end{array}$} & $\mathrm{OC}$ & $\mu \mathrm{gC}$ & 0.317 & 0.129 & 0.386 & $5 \%$ \\
\hline & $\mathrm{EC}$ & & 0.001 & 0.003 & 0.009 & \\
\hline & Opt. EC & & 0.017 & 0.008 & 0.024 & \\
\hline $\begin{array}{l}\text { Nephelometer (Optec, } \\
\text { NGN2) }\end{array}$ & $b_{\text {scat }}$ & $\mathrm{Mm}^{-1}$ & 0.554 & 1.441 & 4.321 & $10 \%$ \\
\hline $\begin{array}{l}\text { Aerosol Spectrometer } \\
(\text { Grimm, 265) }\end{array}$ & $\mathrm{PM}_{10} / \mathrm{PM}_{2.5} / \mathrm{PM}_{1.0}$ & $\mu \mathrm{g} \mathrm{m}^{-3}$ & & & 1.0 & 1) $2 \%$ \\
\hline
\end{tabular}

1) Reproducibility of the aerosol spectrometer in particle counting.

filtered air measurement (dynamic blank). The uncertainty of this system was reported to be 5\% (Polidori et al., 2006). Comparison study between our semi-continuous OC/EC analyzer and $24 \mathrm{~h}$ filter samples was previously performed at an urban site in Beijing, China during the CAREBeijing2006 campaign (Jung et al., 2009a). Good correlation was observed between the semi-continuous and $24 \mathrm{~h}$ filter based OC/EC data; i.e., OC with slope (x-axis: filter based, y-axis: semi-continuous) of $1.07\left(R^{2}=0.86\right)$ and $\mathrm{EC}$ with slope of $0.94\left(R^{2}=0.94\right)$.

The 7- $\lambda$ Aethalometer (Magee Scientific, Model AE31) measures the optical attenuation (absorbance) of light from LED lamps emitting at seven wavelengths (370, 470, 520, $590,660,880$, and $950 \mathrm{~nm}$ ) with a typical half-width of $20 \mathrm{~nm}$ (Hansen, 2005). The flow rate was maintained at 4 LPM corresponding to a $2.5 \mu \mathrm{m}$ cut-point of $\mathrm{PM}_{2.5}$ cyclone (BGI inc., SCC1.829). Detection limit of the aethalometer $\mathrm{BC}$ was determined to be $0.16-0.28 \mu \mathrm{gm}^{-3}$ with a flow rate of 4 LPM and 5 min time interval (Table 2), calculated as three times the standard deviation $(3 \sigma)$ of the dynamic blank. Uncertainty of the aethalometer reported by the manufacturer is $\pm 5 \%$ (Hansen, 2005). To account for the "shadowing" effect due to filter loading (decrease in aethalometer sensitivity), $R$ (ATN), the loading correction was done as suggested by Weingartner et al. (2003). Even though humidity effect on the aethalometer BC measurement was negligible (Schmid et al., 2006), the aerosol was dried to $\mathrm{RH}<40 \%$ by a diffusion dryer prior to particle detection.

Several studies address the effect of water uptake by aerosols on aerosol light absorption (Redemann et al., 2001; Nessler et al., 2005). Redemann et al. (2001) es- timated RH enhancement factors for absorption, $\chi(\mathrm{RH})$ $\left(=b_{\text {abs }}(\mathrm{RH}) / b_{\text {abs }}(\right.$ dry $\left.)\right)$ of internally mixed soot up to 1.35 in the $\mathrm{RH}$ range of $30 \%-95 \%$ based on the core/shell aerosol model. Nessler et al. (2005) estimated $\chi(\mathrm{RH})$ of internally mixed aerosols in summer (0.94 to 1.78) and in winter (0.84 to 1.53 ) in the $\mathrm{RH}$ range of $0 \%$ to $99 \%$ based on the core/shell aerosol model. These studies demonstrate that the effect of water uptake by aerosols on aerosol light absorption is not negligible for internally mixed soot. Higher water uptake by quartz filter used in the aethalometer can further influence multiple scattering within the filter media and also shadowing effect, resulting in measurement error of the aethalometer. Thus, this study measured $\mathrm{BC}$ under dry condition. Chemical composition of coated shell of BC, size distribution of $\mathrm{BC}$, and their exact mixing state are essential parameters for the core/shell aerosol model. Since those parameters were not measured in this study, RH effect on aerosol light absorption was not considered here.

\subsection{Nephelometer and aerosol spectrometer}

Light scattering coefficient, $b_{\text {scat }}$ at $550 \mathrm{~nm}$ of ambient particles was measured by an ambient nephelometer (Optec, Model NGN2) with an open air inlet. ZERO air calibration was usually performed more often (every $12 \mathrm{~h}$ ) than SPAN gas calibration, which was done every week with HFC-134a (Suva 134a). Uncertainty of the ambient nephelometer reported by the manufacturer is $\pm 10 \%$ with 2 min time interval (Optec, 1993). For time resolution of $2 \mathrm{~min}$, the detection limit of $b_{\text {scat }}$ was determined to be $4.32 \mathrm{Mm}^{-1}$, calculated as $3 \sigma$ of the dynamic blank. 
Table 3. Multiple scattering correction factor $\left(C^{*}\right)$ of different mixing states of EC in previous calibration studies.

\begin{tabular}{lll}
\hline Aerosol type & $C^{*}$ & Reference \\
\hline Pure or external mixture of soot & $1.8-2.2$ & Arnott et al., 2005 at $\lambda=521 \mathrm{~nm}$ \\
Urban (internally mixture) & 3.7 & \\
Pure or external mixture of soot & 2.14 & Weingartner et al., 2003, at $\lambda=532 \mathrm{~nm}$ \\
Soot coated with organic carbon (internally mixture) & 3.6 & \\
Ambient aerosol (internally mixture) & 4.55 & Schmid et al., 2006, at $\lambda=532 \mathrm{~nm}$ \\
Pure or external mixture of soot & $\mathbf{2 . 1}$ & Suggested by Schmid et al. at $\lambda=532 \mathrm{~nm}$ \\
Internally mixture of soot & 4.0 & \\
\hline
\end{tabular}

$\mathrm{PM}_{10} / \mathrm{PM}_{2.5} / \mathrm{PM}_{1.0}$ mass concentrations and particle number size distribution in the range of $0.25-32 \mu \mathrm{m}$ were measured by an aerosol spectrometer system (Grimm Labortechnik Ltd., Model 265). The aerosol spectrometer system consists of an aerosol spectrometer (Grimm Labortechnik Ltd., Model 1.108) and a dry air dilution system combined with a heated sampling system. Measurement principle can be found elsewhere (Grimm, 2002; Grimm and Eatough, 2009). Raw particle number and mass concentration were measured every minute under dry condition $(\mathrm{RH}<40 \%)$ by diluting the sample air with dry clean air. Based on automatically controlled inlet heating system with $110^{\circ} \mathrm{C}$ heating for $15 \mathrm{~min}$ and no heating for $15 \mathrm{~min}$, the number concentrations of ambient and refractive aerosols was measured every minute. Excellent correlation of $\mathrm{PM}_{2.5}$ mass concentration between the aerosol spectrometer and $24 \mathrm{~h}$ filter based method was observed during the CAREBeijing2006 campaign with a slope of $1.0\left(R^{2}=0.98\right)$ (Jung et al., 2009a). The detection limit and uncertainties of the measurement systems are summarized in Table 2 .

\subsection{Skyradiometer}

Aerosol optical thickness (AOT) was determined for every 10 min time interval based on the Skyradiometer (PREDE, Model POM-02) data measured at 11 channels (315, 340, 380, 400, 500, 675, 870, 940, 1020, 1600, and $2200 \mathrm{~nm}$ ). Skyradiometer has two observation geometries, which are principal method and almucantar method (Nakajima et al., 1996). This study conducted vertical and horizontal measurements sequentially in each cycle based on the principal and almucantar methods, respectively, for $10 \mathrm{~min}$ time interval. The software code SKYRAD.pack (Nakajima et al., 1996) was used to retrieve AOT from data of direct and diffuse solar radiation. Only cloud-screened and qualityassured data were used in this study.

\section{Analytical method}

It is well-known that light attenuation coefficient, $b_{\mathrm{ATN}}$ is generally larger than light absorption coefficient, $b_{\text {abs }}$ due to optical interactions of the filter substrate with the deposited aerosol (Petzold et al., 1997; Kopp et al., 1999; Ballach et al., 2001; Weingartner et al., 2003; Arnott et al., 2005). The most significant filter-particle interactions and the resulting biases are: (1) multiple scattering of light by the filter fibers enhances the optical path length, resulting in positive bias on $b_{\text {ATN }}$, (2) enhanced absorption of scattered light with increasing filter loading reduces the optical path length, so called "shadowing effect", which reduces $b_{\mathrm{ATN}}$, and (3) the filter reflectance (scattering in backwards hemisphere) and hence the measured attenuation depends on the optical properties of the deposited particles (bias in $b_{\mathrm{ATN}}$ depends on physicochemical properties of the particles).

Because previous studies have already discussed in detail about the retrieval of $b_{\mathrm{abs}}$ from Aethalometer $b_{\mathrm{ATN}}$ (Weingartner et al., 2003; Arnott et al., 2005; Schmid et al., 2006), brief description is given here.

$b_{\text {abs }}$ determined by the Aethalometer can be expressed as (Weingartner et al., 2003; Arnott et al., 2005)

$b_{\mathrm{abs}}=\frac{b_{\mathrm{ATN}}}{C \cdot R(\mathrm{ATN})}=\frac{b_{\mathrm{ATN}}-m_{s} \cdot b_{\mathrm{scat}}}{C^{*} \cdot R(\mathrm{ATN})}$

where the constant factor $C(\geq 1)$ corrects for multiple light scattering effects within the filter and $R(\mathrm{ATN})(\leq 1)$ accounts for the "shadowing" effect due to filter loading (decrease in Aethalometer sensitivity). $C^{*}$ and $\mathrm{m}_{s}$ represent the multiple scattering correction corrected for aerosol scattering and the fraction of $b_{\text {scat }}$, respectively (Schmid et al., 2006). The attenuation, ATN $\left(=100 \cdot \ln \left(\mathrm{I}_{0} / \mathrm{I}\right)\right)$ is typically given as percentage value and is defined by the relationship between the light intensities transmitted through the particle-laden (I) and a blank spot of the filter $\left(\mathrm{I}_{0}\right)$.

The NOAA/ARL HYSPLIT (HYbrid Single-Particle Lagrangian Trajectory) air mass backward trajectory analysis (Draxler and Rolph, 2003; Rolph, 2003) and Moderate Resolution Imaging Spectro-radiometer (MODIS) satellite image analysis were used to characterize potential source regions 


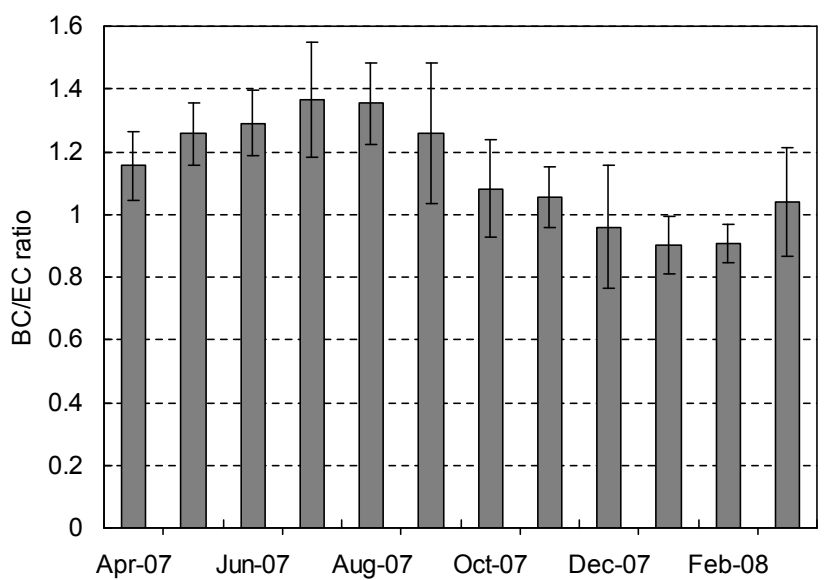

Fig. 2. Temporal variation of monthly average black carbon (BC)/elemental carbon (EC) ratio. Error bars represent standard deviation $(1 \sigma)$ of $\mathrm{BC} / \mathrm{EC}$ ratio.

and the transport pathway of the air mass. Air mass backward trajectories ended at the measurement site were computed for 500 and $1000 \mathrm{~m}$ above ground level (AGL) heights using the HYSPLIT model. All back-trajectories were calculated at 02:00 UTC and 05:00 UTC (local time 11:00 and 14:00, respectively) extending to $96 \mathrm{~h}$ backward with $1 \mathrm{~h}$ time interval. Aerosol optical thickness (AOT) data retrieved by the new V5.2 version of the NASA MODIS algorithm, called Collection 005 (C005) (Levy et al., 2007a, b) were used in this study. AOT data which is part of the MODIS Terra/Aqua Level-2 gridded atmospheric data product are available on the MODIS web site http://modis.gsfc.nasa.gov/.

\section{Result and discussion}

\subsection{Retrieval of spectral absorption coefficient of atmospheric aerosols}

To retrieve $b_{\mathrm{abs}}$ from aethalometer $b_{\mathrm{ATN}}$, it is essential to determine the multiple scattering correction factor, $C^{*}$ accurately which varies depending on the mixing state of EC. Since it is difficult to determine the mixing state of $\mathrm{EC}$ in the atmosphere, internal or external mixture of EC was assumed in the most of models and field studies (Naoe and Okada, 2001; Pósfai et al., 1999). Previous calibration studies involving $C^{*}$ of different mixing states of EC are summarized in Table 3. $C^{*}$ was reported to be $1.8-2.2$ and 3.6-4.55 for the external mixture and the internal mixture of EC, respectively (Arnott et al., 2005; Schmid et al., 2006; Weingartner et al., 2003).

Figure 2 shows monthly variation of $\mathrm{BC} / \mathrm{EC}$ ratio based on optically measured $\mathrm{BC}$ and thermally measured $\mathrm{EC}$ by the aethalometer and the semi-continuous Sunset OC/EC analyzer, respectively. Because the aethalometer BC is obtained from the optical attenuation of light by EC deposited

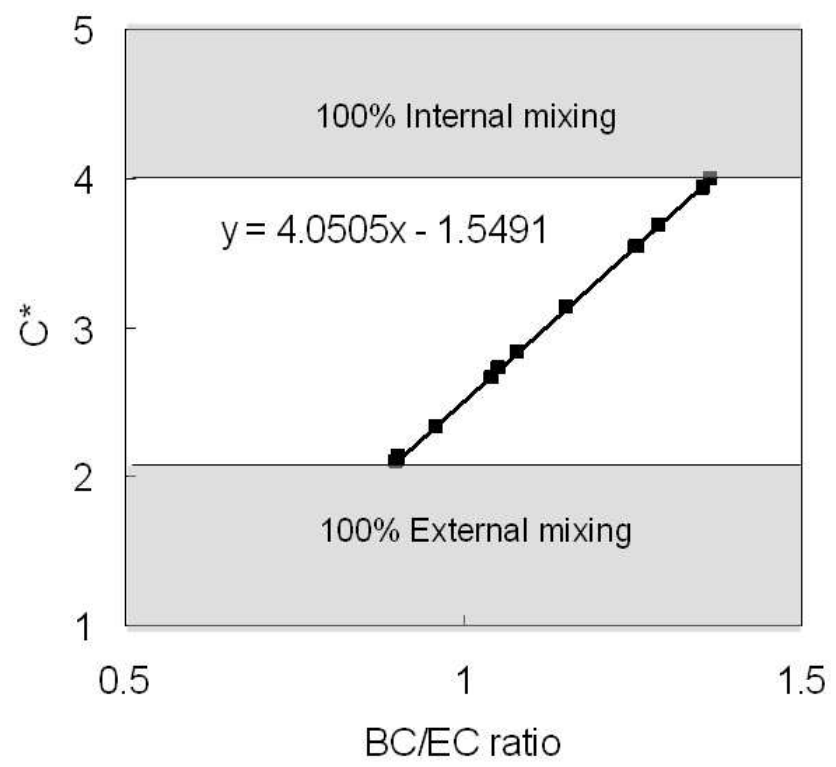

Fig. 3. Retrieval of multiple scattering correction factor $\left(C^{*}\right)$ for aethalometer measurement based on $\mathrm{BC} / \mathrm{EC}$ ratio.

on a filter, the magnitude of BC is highly influenced by additional absorption by light absorbing aerosols such as dust particles and organic aerosol as well as the mixing state of EC. Petzold et al. (1997) argued that, for internal mixtures of EC and some mainly scattering material, an aethalometer response was enhanced by up to a factor of 2 (for EC contents of $\sim 3 \%$ ), compared to external mixtures. Weingartner et al. (2003) also reported that spectral absorption (370$950 \mathrm{~nm}$ ) of an aethalometer was enhanced by up to a factor of 1.5 for soot coated with organic aerosol, compared to externally mixed soot with ammonium sulfate. They also found that almost no enhancement of an aethalometer absorption at $880 \mathrm{~nm}$ was observed for externally mixed soot with ammonium sulfate relative to reference soot. Since this study used $\mathrm{BC}$ measured at $880 \mathrm{~nm}$ where only EC is absorbing aerosol, the change in measured $\mathrm{BC}$ value is mainly due to the change of mixing state of EC. In contrary, thermally measured EC is independent from the mixing state of EC.

$\mathrm{BC} / \mathrm{EC}$ ratio shows clear monthly variation with high values in summer and low values in winter as seen in Fig. 2. The enhanced $\mathrm{BC}$ concentration in summer is mainly due to the increase of absorption capacity of EC through the internal mixing (or coating) with organic and/or inorganic aerosols. Snyder and Schauer (2007) also reported the enhancement of light absorption capacity of EC through the coating with secondary organics. Thus, this study used BC/EC ratio as an indicator of the mixing state of EC.

This study determined $C^{*}$ based on $\mathrm{BC} / \mathrm{EC}$ ratio, assuming most of $\mathrm{EC}$ in summer (highest $\mathrm{BC} / \mathrm{EC}$ ratio) is internally mixed while that in winter is externally mixed (lowest $\mathrm{BC} / \mathrm{EC}$ ratio) with secondary aerosols. $C^{*}$ values of 2.1 and 4.0 were used in this study for external and internal mixtures 


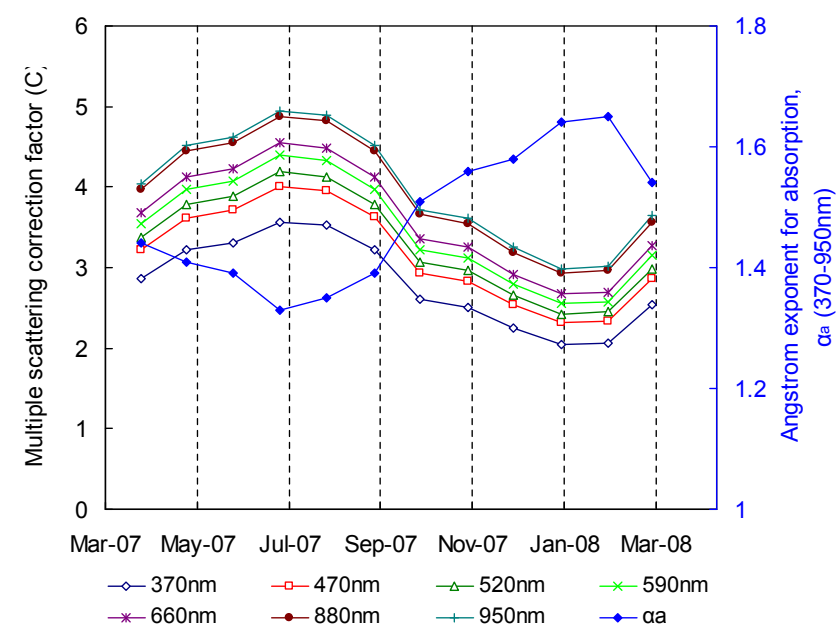

Fig. 4. Determination of the Ångström exponent for absorption $\left(\alpha_{a}\right)$ in the range of $370 \mathrm{~nm}-950 \mathrm{~nm}$ and multiple scattering correction factor $(\mathrm{C})$ at the measurement site.

of EC, respectively, suggested by Schmid et al. (2006). Retrieval of $C^{*}$ based on $\mathrm{BC} / \mathrm{EC}$ ratio is shown in Fig. 3. During the measurement period, monthly average $\mathrm{BC} / \mathrm{EC}$ ratio varies from $0.90 \pm 0.09$ to $1.37 \pm 0.18$. Regression equation of $C^{*}$ versus $\mathrm{BC} / \mathrm{EC}$ ratio was obtained as;

$C^{*}=4.05 \cdot \frac{B C}{E C}-1.55$

Multiple scattering correction factor, $C^{*}$ and Ångström exponent of aerosol light absorption between 370 and $950 \mathrm{~nm}$, $\alpha_{a}(370-950 \mathrm{~nm})$ shown in Fig. 4. $\alpha_{a}(370-950 \mathrm{~nm})$ showed clear monthly variation with low values (1.33-1.39) in summer and high values $(1.58-1.65)$ in winter. This seasonal trend can be partially explained by seasonal trend of particulate PAHs which is one of the major strong UV absorbing compounds. Previous study in Seoul, Korea reported clear seasonal trend of PAHs with high values in winter (Park et al., 2002). They reported that particulate PAHs in winter were almost 8 times higher than in summer. Seasonal variations of PAH concentration is generally attributed to increased emissions during the cold season, principally fossil fuel combustion for space heating purposes. Other factors known to contribute to higher wintertime PAHs concentrations include lower atmospheric mixing heights, lower temperatures, and decreased photochemical oxidation (Park et al., 2002).

Site specific mass attenuation efficiency, $\sigma_{\mathrm{ATN}}(=$ $b_{\mathrm{ATN}} / E C$ ) was determined based on thermally measured EC and the aethalometer raw $b_{\mathrm{ATN}}$ data. Mass absorption efficiency, $\sigma_{\mathrm{abs}}\left(=b_{\mathrm{abs}} / E C\right)$ was determined based on thermally measured $\mathrm{EC}$ and $b_{\mathrm{abs}}$. Figure 5 shows seasonal variations of spectral $\sigma_{\mathrm{ATN}}$ and $\sigma_{\mathrm{abs}}$. Magee BC in Fig. 5 represents $\sigma_{\mathrm{ATN}}$ widely used in $\mathrm{BC}$ calculation from $\mathrm{AE} 31$ aethalometer. It was found that the AE31 aethalometer underestimated
BC by $20 \%$ in winter than thermally measured EC while it overestimated 20,40 , and $10 \%$ in spring, summer, and fall, respectively. These over- or underestimation of $\mathrm{BC}$ for different season can alter aerosol single scattering albedo significantly, resulted in large uncertainties in radiative transfer calculation. Thus, proper seasonal $\sigma_{\mathrm{ATN}}$ value should be used for filter based BC measurement. $\sigma_{\mathrm{abs}}$ at $550 \mathrm{~nm}$ was obtained to be $9.0 \pm 1.3,8.9 \pm 1.5,9.5 \pm 2.0$, and $10.3 \pm 1.7 \mathrm{~m}^{2} \mathrm{~g}^{-1}$ in spring, summer, fall, and winter, respectively. Annual mean $\sigma_{\mathrm{abs}}$ of $9.4 \pm 1.8 \mathrm{~m}^{2} \mathrm{~g}^{-1}$ at the measurement site was slightly lower than that of $10.5 \pm 0.7 \mathrm{~m}^{2} \mathrm{~g}^{-1}$ observed at six different locations in Asia (Japan, Korea, China, and Thailand) (Kondo et al., 2009).

\subsection{Retrieval of spectral scattering coefficient of atmospheric aerosols}

Since the nephelometer used in this study only measures $b_{\text {scat }}$ at $550 \mathrm{~nm}$, spectral $b_{\text {scat }}$ was retrieved based on $b_{\text {scat }}$ at $550 \mathrm{~nm}$ and spectral dependence of $b_{\text {abs }}$. First, light extinction coefficient, $b_{\text {ext }}$ at $550 \mathrm{~nm}$ was obtained from the sum of $b_{\text {scat }}$ and $b_{\text {abs }}$ at $550 \mathrm{~nm}$. And then $b_{\text {ext }}$ at each wavelength was retrieved based on Ångström exponent of aerosol light extinction, $\alpha_{e}$ obtained from column integrated AOT measured by the Skyradiometer. This study assumes vertically well mixed aerosols inside boundary layer in calculating the spectral dependence of $b_{\text {ext }}$ from Ångström exponent obtained by the Skyradiometer. Also it can be assumed that aerosol optical depth is dominated by these particles within the boundary layer at urban sites with high aerosol loading.

$b_{\text {ext }}(\lambda)=b_{\text {ext }}(550 \mathrm{~nm}) \cdot\left(\frac{\lambda}{550 \mathrm{~nm}}\right)^{-\alpha_{e}}$

where $\alpha_{e}$ at short and long visible regions were obtained from spectral AOT measured by the Skyradiometer as;

$$
\begin{aligned}
& \alpha_{e-} \operatorname{vis}(S W) \\
& =-\frac{\log (\text { AOT }(550 \mathrm{~nm}))-\log (\text { AOT }(380 \mathrm{~nm}))}{\log (550 \mathrm{~nm})-\log (380 \mathrm{~nm})}
\end{aligned}
$$

$\alpha_{e-} \operatorname{vis}(L W)$

$$
=-\frac{\log (\text { AOT }(870 \mathrm{~nm}))-\log (\text { AOT }(550 \mathrm{~nm}))}{\log (870 \mathrm{~nm})-\log (550 \mathrm{~nm})}
$$

Finally, spectral $b_{\text {scat }}$ was obtained from spectral $b_{\text {ext }}$ after subtracting spectral $b_{\mathrm{abs}}$. Seasonal variations of spectral $b_{\mathrm{abs}}$ and $b_{\text {scat }}$ as well as $\alpha_{a}$ and Ångström exponent of $b_{\text {scat }}, \alpha_{s}$ between 370 and $950 \mathrm{~nm}$ are shown in Fig. 6. Highest $b_{\text {abs }}$ was observed in winter $\left(34.8 \pm 24.2 \mathrm{Mm}^{-1}\right)$, followed by fall, spring, and summer. Highest value in winter can be attributed to low boundary layer height and increased emission from low temperature combustion. However, lowest value in summer is mainly attributed to clean southerly wind from Pacific Ocean. Highest $b_{\text {scat }}\left(264.6 \pm 226.3 \mathrm{Mm}^{-1}\right)$ in spring is 

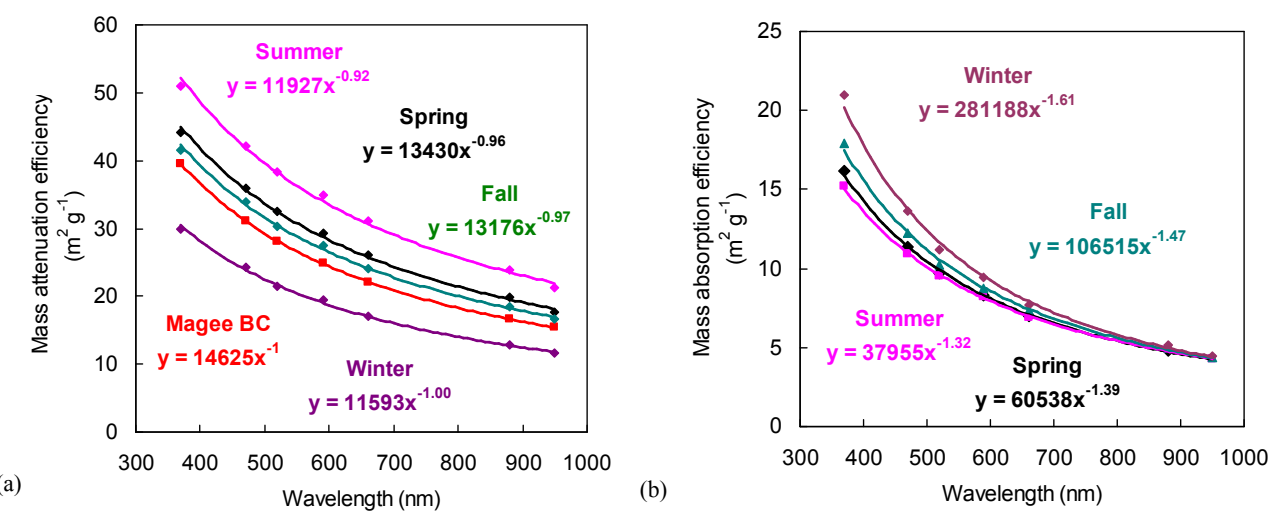

Fig. 5. Seasonal variations of (a) specific attenuation efficiency of aethalometer BC and (b) mass absorption efficiency of EC as a function of wavelength.
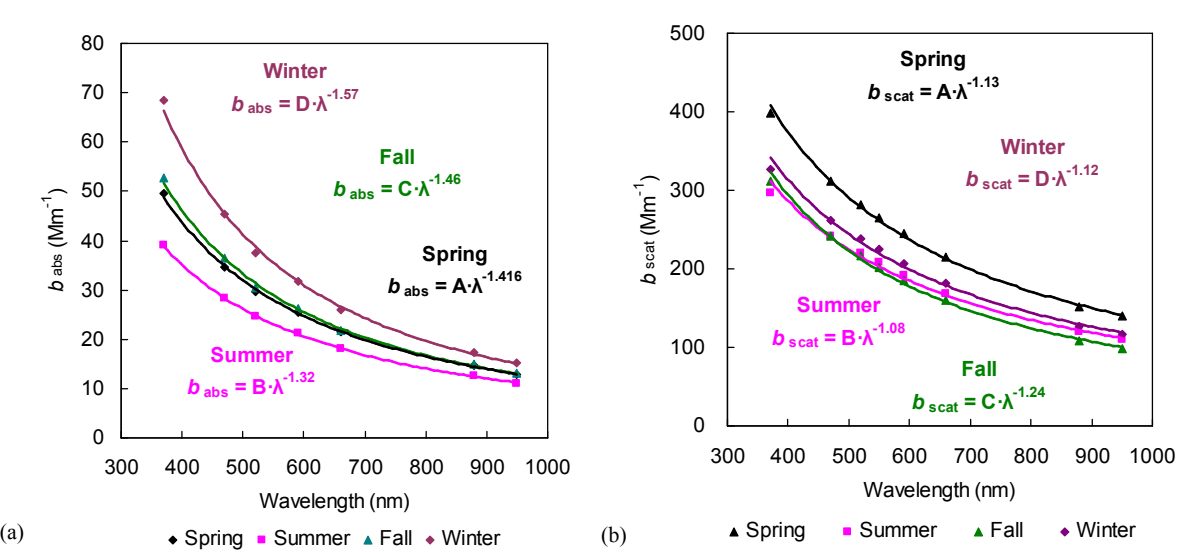

Fig. 6. Seasonal variations of (a) light absorption $\left(b_{\mathrm{abs}}\right)$ and (b) light scattering coefficient $\left(b_{\text {scat }}\right)$ as a function of wavelength.

mainly attributed to frequent transport of pollution and Asian dust aerosols from Asian continent (Kim et al., 2001, 2006; Park and Kim, 2006; Lee et al., 2007; Kim, 2008). $\alpha_{s}$ was determined to be $1.13,1.08,1.24$, and 1.12 in spring, summer, fall, and winter, respectively. Highest $\alpha_{s}$ in fall indicates the dominance of freshly emitted fine particle such as postharvest biomass burning (Balis et al., 2003; Lee et al., 2005; Badarinath et al., 2009; Ryu et al., 2006).

It has been well known that hygroscopic urban particles grow in summer as RH increases. During the entire measurement period, $b_{\text {scat }}$ of dry particle was also measured. From the $b_{\text {scat }}$ of dry and ambient particles, light scattering enhancement factor, $f(\mathrm{RH})\left(=b_{\text {scat }}(\mathrm{RH}) / b_{\text {scat }}(\right.$ dry $\left.)\right)$ was calculated as a function of RH and shown in Fig. 7. Average RH in summer and winter were $74.7 \pm 13.6 \%$ and $52.0 \pm 18.2 \%$, respectively. Average $f(\mathrm{RH}=75 \%)$ and $f(\mathrm{RH}=52 \%)$ were obtained to be $1.7 \pm 0.4$ and $1.2 \pm 0.2$, respectively. Higher average $f(\mathrm{RH})$ in summer indicate increase of particle size by water uptake.

Kim et al. (2007a) continuously measured $\mathrm{PM}_{2.5}$ aerosol chemical composition in Seoul, Korea from the spring of
2003 to the winter of 2004 . They reported higher watersoluble (the sum of sulfate, nitrate, and ammonium) fraction to $\mathrm{PM}_{2.5}$ mass concentration in summer $(\sim 57 \%)$ than those in fall $(\sim 44 \%)$ and in winter $(\sim 42 \%)$. Thus, lowest $\alpha_{s}$ in summer is believed to be due to not only the increase of particle size through water uptake under the enhanced RH but also highly hygroscopic nature of atmospheric aerosols in summer. The HYSPLIT air mass backward trajectory analyses clearly showed that most air masses are from the Pacific Ocean in summer. Stagnant synoptic meteorological pattern was frequently observed in Seoul in the beginning of summer (Kim, et al., 2007b), which may enhance secondary aerosol formation.

\subsection{Spectral single scattering albedo of atmospheric aerosols}

Single scattering albedo, SSA of ambient aerosol was obtained from the ratio of $b_{\text {scat }}$ to $b_{\text {ext }}\left(=b_{\text {scat }}+b_{\text {abs }}\right)$ and shown in Fig. 8. Average SSA at $550 \mathrm{~nm}$ was $0.88 \pm 0.07$, $0.84 \pm 0.10,0.82 \pm 0.09$, and $0.84 \pm 0.06$ in spring, summer, fall, and winter, respectively, with an annual mean of 


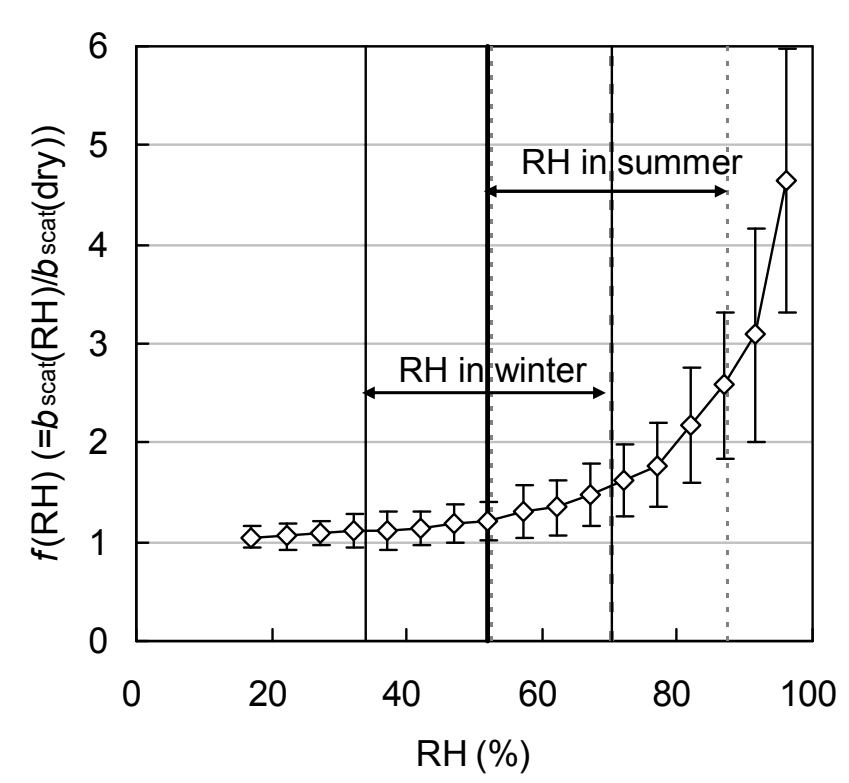

Fig. 7. Humidity dependence light scattering enhancement factor, $f(\mathrm{RH})\left(=b_{\text {scat }}(\mathrm{RH}) / b_{\text {scat }}(\right.$ dry $\left.)\right)$. Error bars represent $1 \sigma$. Bold vertical solid and dotted lines represent average $\mathrm{RH}$ in winter and summer, respectively. Arrows indicate $1 \sigma$.

$0.85 \pm 0.09$. It is comparable to 0.86 in Guangzhou (Andreae et al., 2008) but slightly higher than $0.81-0.85$ measured at a rural site of Xianghe in China ( $\sim 70 \mathrm{~km}$ southeast of Beijing) (Li et al., 2007) and 0.81 in Beijing (Bergin et al., 2001). During the entire measurement period, highest $\mathrm{EC} \mathrm{PM}_{10}$ ratio was obtained in fall $(7.8 \pm 3.8 \%)$, followed by summer $(7.4 \pm 5.8 \%)$, winter $(6.2 \pm 2.5 \%)$, and spring $(4.6 \pm 2.8 \%)$. Lowest SSA in fall can be explained by the highest $\mathrm{EC} / \mathrm{PM}_{10}$ ratio. Even though similar $\mathrm{EC} / \mathrm{PM}_{10}$ ratios were obtained in spring and summer, higher SSA was observed in summer. This was mainly due to the enhanced $b_{\text {scat }}$ under the high RH condition in summer. Highest SSA in spring can be attributed to the enhancement of $b_{\text {scat }}$ by Asian dust and longrange transport pollution aerosols from Asian continent (Kim et al., 2001; Lee et al., 2007).

Ångström exponent of SSA, $\alpha_{S S A}$ in short visible (370$520 \mathrm{~nm})$ and long visible $(590-950 \mathrm{~nm})$ wavelength for different seasons are also shown in Fig. 8. Strongest spectral dependence of SSA was observed in winter with $\alpha_{S S A}$ in the short visible of -0.18 . This strong spectral dependence in the short wavelength was mainly attributed to the increase of UV absorbing organic aerosols. SSA at $550 \mathrm{~nm}$ under relatively dry $(\mathrm{RH}<60 \%)$ and humid $(\mathrm{RH}>60 \%)$ conditions are also plotted as a function $\mathrm{PM}_{10}$ mass concentration in Fig. 8. Each data point in Fig. 8 represents average value with one

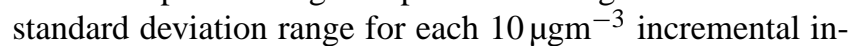
terval for $\mathrm{PM}_{10}<100 \mu \mathrm{gm}^{-3}$ and for $30 \mu \mathrm{gm}^{-3}$ incremental interval for $\mathrm{PM}_{10}>100 \mu \mathrm{gm}^{-3}$. The difference of SSA under the dry and humid conditions $(\triangle \mathrm{SSA})$ is also plotted in Fig. 8.
SSA for $\mathrm{PM}_{10}<10 \mu \mathrm{g} \mathrm{m}^{-3}$ decreased down to $0.71 \pm 0.12$ and $0.72 \pm 0.12$ under relatively dry and humid conditions, respectively, which reveals that background aerosols are highly absorbing. As $\mathrm{PM}_{10}$ mass increases, SSA increases up to $0.90 \pm 0.02$ and $0.94 \pm 0.02$ for $\mathrm{PM}_{10}<200 \mu \mathrm{gm}^{-3}$ under the dry and humid conditions, respectively. It was found that average SSA under the humid condition is $\sim 7 \%$ higher than that under the dry condition mainly due to the enhanced aerosol scattering by water uptake. Interestingly as $\mathrm{PM}_{10}$ increases $>100 \mu \mathrm{gm}^{-3}, \Delta \mathrm{SSA}$ sharply decreases from $\sim 0.075$ to $\sim 0.035$. Since high $\mathrm{PM}_{10}$ mass concentration $>150 \mu \mathrm{g} \mathrm{m}^{-3}$ was observed during the Asian dust periods as summarized in Table 4 , decreasing trend of $\triangle$ SSA under high aerosol loading can be explained by increased contribution of hydrophobic dust particles to total $\mathrm{PM}_{10}$ mass concentration.

Frequency distributions of SSA at $550 \mathrm{~nm}$ are shown in Fig. 9 for four different seasons. Blue triangle and red diamond represent relatively clean $\left(\mathrm{PM}_{10}<50 \mu \mathrm{g} \mathrm{m}^{-3}\right)$ and polluted $\left(\mathrm{PM}_{10}>100 \mu \mathrm{gm}^{-3}\right)$ periods, respectively. Bi-modal distribution of SSA centered at 0.82 (first mode) and 0.94 (second mode) are clearly observed in all season. The mass fraction of carbonaceous aerosols, especially EC to total PM mass concentration dominantly increased during the clean periods in the megacities of Korea (Kim et al., 2007a) and China (Jung et al., 2009a,b), resulting in the dominance of SSA in the first mode. However, secondary aerosols such as sulfate and nitrate were dominantly increased during the polluted periods, resulting in the dominance of SSA in the second mode.

The highest frequency of SSA in spring is observed in the second mode, which can be attributed to frequent occurrence of Asian dust and haze events (Kim et al., 2001, 2006; Lee et al., 2007; Kim, 2008). In contrary, the highest frequency of SSA in winter is observed in the first mode, which can be explained by the increased contribution of light absorbing aerosol and low RH in winter. The frequency of SSA in the first mode increases from spring to winter while it decreases in the second mode. Even though average $\mathrm{PM}_{10}$ mass concentration was similar between summer and fall, frequency distribution of SSA in the second mode was slightly higher in summer. This is mainly due to enhanced aerosol scattering by water uptake under high $\mathrm{RH}$ and enhanced formation of water-soluble aerosols in summer.

\subsection{Characteristics of spectral aerosol optical properties of long-range transport aerosols}

Temporal variation of hourly average $\mathrm{PM}_{10}$ mass concentration at the measurement site is plotted in Fig. 10. During the entire measurement period, several severe haze events were observed. These severe haze events were categorized into either long-range transport pollution (LTP) or Asian dust (AD) cases based on the analysis results of MODIS AOT and Hysplit air mass backward trajectories. LTP haze and Asian dust 


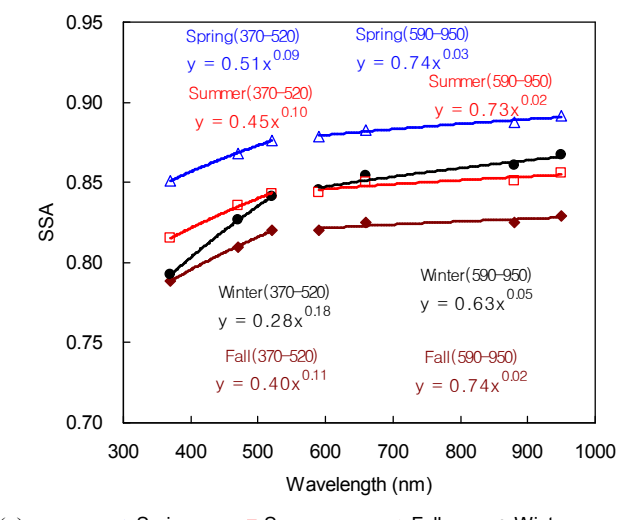

(a)

$$
\triangle \text { Spring } \quad \square \text { Summer } \quad \text { Fall } \quad \bullet \text { Winter } \quad(b)
$$

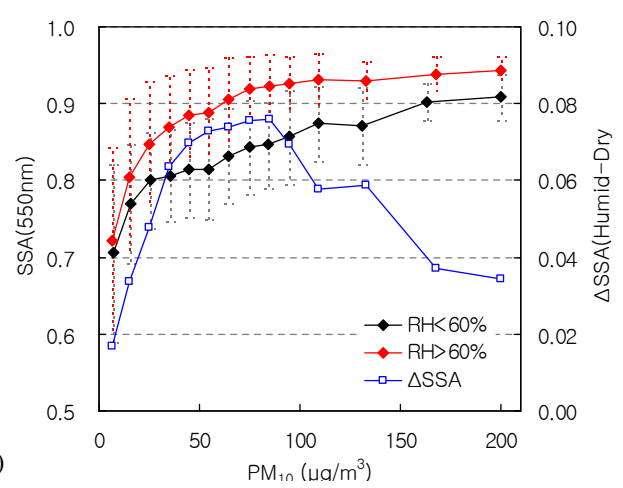

Fig. 8. Seasonal variations of (a) aerosol single scattering albedo (SSA) as a function of wavelength and (b) SSA at $550 \mathrm{~nm}$ wavelength as a function of $\mathrm{PM}_{10}$ mass concentration under relatively dry $(\mathrm{RH}<60 \%)$ and humid $(\mathrm{RH}>60 \%)$ conditions, respectively.
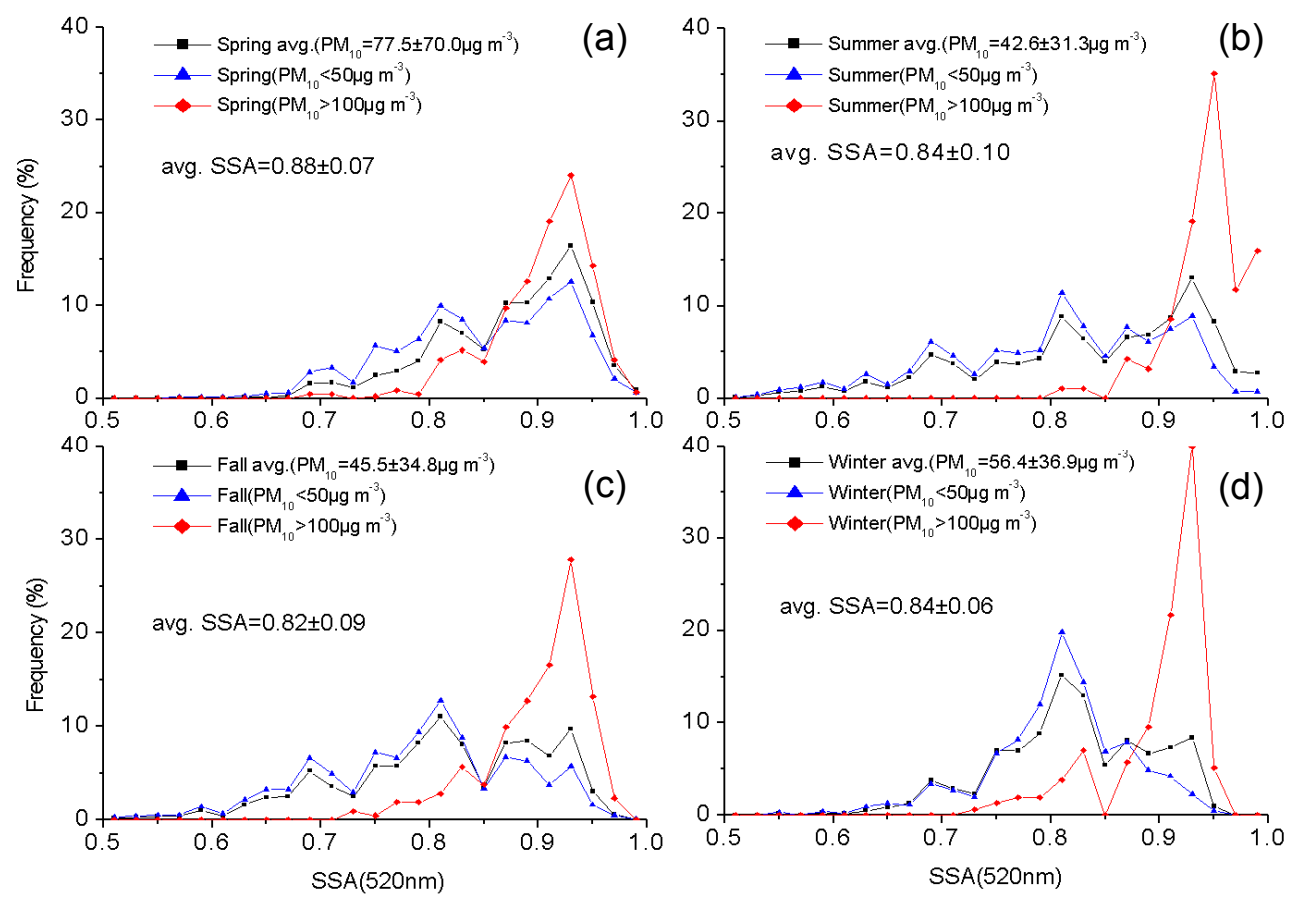

Fig. 9. Frequency distributions of SSA at $550 \mathrm{~nm}$ during (a) spring, (b) summer, (c) fall, and (d) winter, respectively. Blue triangle and red diamond represent relatively clean $\left(\mathrm{PM}_{10}<50 \mu \mathrm{gm}^{-3}\right)$ and polluted $\left(\mathrm{PM}_{10}>100 \mu \mathrm{gm}^{-3}\right)$ periods, respectively.

events are expressed as red and black circles, respectively, in Fig. 10. Most of Asian dust event occurred in spring except two cases in winter.

\subsubsection{Asian dust particles}

Because Korea is located in the downwind area of Asian continent, dust aerosol particles originated from desert regions in China are frequently transported over Korean peninsular in spring (Kim et al., 2001; Park and Kim, 2006; Kim, 2008). MODIS RGB image, AOT, and AOT Ångström exponent on
31 March 2007 are shown in Fig. 11. High aerosol loadings with AOT $>1.0$ are observed over China. Asian dust layer is clearly seen over northern China to Yellow Sea with high AOT of $>1.0$ and low Ångström exponent of $<0.4$. During the entire measurement period, Asian dust events were observed five times in spring and twice in winter. Average $\mathrm{PM}_{10}$ mass concentration during the Asian dust periods ranged $92.3{\mu \mathrm{gm}^{-3}}^{-3} 1089.0 \mu \mathrm{gm}^{-3}$. Severe Asian dust events originated from Nei Mongol desert were observed during 31 March-1 April 2007 (AD2_07) with an average $\mathrm{PM}_{10}$ of $544.1 \pm 250.6 \mu \mathrm{g} \mathrm{m}^{-3}$. Aerosol physical and optical 
Table 4. Summary of aerosol physical and optical properties measured during different Asian dust periods.

\begin{tabular}{|c|c|c|c|c|c|c|c|c|}
\hline Category & Period & $\mathrm{PM}_{10}\left(\mu \mathrm{gm}^{-3}\right)$ & $\mathrm{PM}_{2.5}\left(\mu \mathrm{gm}^{-3}\right)$ & $\mathrm{PM}_{2.5} / \mathrm{PM}_{10}(\%)$ & $\mathrm{BC} \mathrm{PM}_{10}(\%)$ & $\mathrm{RH}(\%)$ & $\alpha_{e(340-550 \mathrm{~nm})}$ & $\alpha_{e(550-1020 \mathrm{~nm})}$ \\
\hline AD1_07 & 27-28 Mar 2007 & $253.8 \pm 45.0$ & $86.9 \pm 28.0$ & 36.5 & $2.8 \pm 1.2$ & $69.2 \pm 7.6$ & 0.39 & 0.44 \\
\hline AD2_07 & 31 Mar-1 Apr 2007 & $544.1 \pm 250.6$ & $74.9 \pm 34.0$ & 14.3 & $0.9 \pm 0.3$ & $60.5 \pm 19.0$ & 0.13 & 0.11 \\
\hline AD3_07 & 8 May 2007 & $173.7 \pm 51.1$ & $108.4 \pm 7.9$ & 66.2 & $3.7 \pm 0.8$ & $49.4 \pm 7.1$ & 0.56 & 0.47 \\
\hline AD4_07 & 25-26 May 2007 & $252.2 \pm 59.2$ & $154.6 \pm 48.1$ & 60.2 & $2.1 \pm 0.6$ & $64.4 \pm 16.5$ & 0.18 & 0.17 \\
\hline AD5_07 & 29 Dec 2007 & $303.6 \pm 77.0$ & $104.4 \pm 11.2$ & 35.8 & $0.4 \pm 0.3$ & $52.9 \pm 13.7$ & 0.03 & 0.03 \\
\hline AD1_08 & 12 Feb 2008 & $123.8 \pm 18.6$ & $33.4 \pm 5.4$ & 27.2 & $0.8 \pm 0.3$ & $23.6 \pm 4.5$ & 0.36 & 0.36 \\
\hline AD2_08 & 16-17 Mar 2008 & $149.6 \pm 13.2$ & $48.5 \pm 4.0$ & 32.5 & $1.3 \pm 0.4$ & $43.2 \pm 16.1$ & NA & NA \\
\hline
\end{tabular}

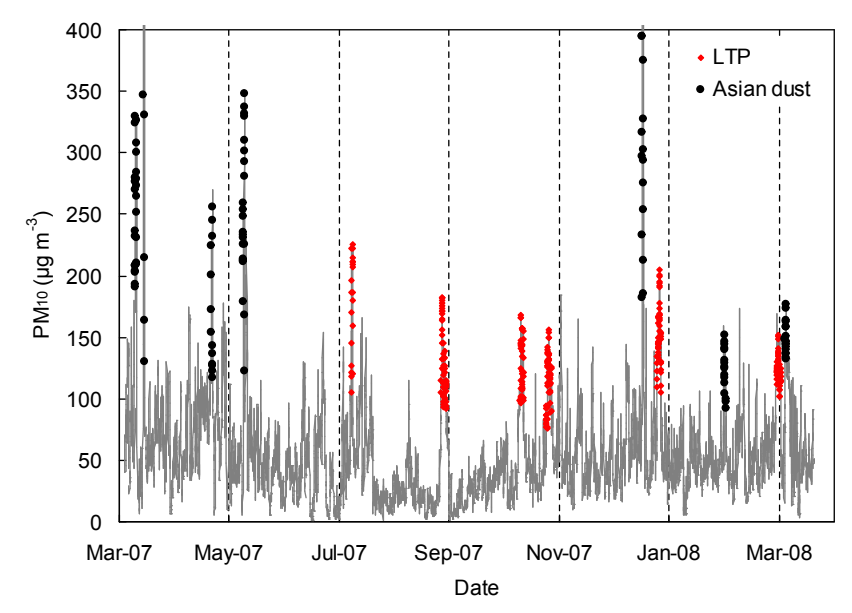

Fig. 10. Temporal variation of $\mathrm{PM}_{10}$ mass concentration in Seoul, Korea during the entire measurement period. Red and black circles represent long-range transport pollution (LTP) and Asian dust periods, respectively.

properties observed during the Asian dust events are summarized in Table 4.

MODIS RGB images and Hysplit air mass backtrajectories arriving at the measurement site during the Asian dust periods are shown in Fig. 12. Blue and yellowish green lines represent backward trajectories arriving at 500 and $1000 \mathrm{~m}$ AGL heights, respectively. Most of air masses during the Asian dust periods were originated from northern China near Nei Mongol desert and transported to the measurement site.

Air masses during the AD1_07 (27-28 March 2007), AD3_07 (8 May 2007), and AD4_07 (25-26 May 2007) periods were originated from northern China and then transported across eastern China. Transports of anthropogenic aerosols from eastern China were also clearly observed during the AD1_07 and AD3_07 periods. Many hot spots of biomass burning were observed in eastern coastal areas of China during the AD4_07 period. Therefore, relatively high $\mathrm{PM}_{2.5} / \mathrm{PM}_{10}$ mass ratio and $\mathrm{BC} / \mathrm{PM}_{10}$ ratio during those periods can be attributed to long-range transport anthropogenic aerosols from eastern China. On the other hand, low $\mathrm{PM}_{2.5} / \mathrm{PM}_{10}$ mass ratio $<\sim 0.4$ and $\mathrm{BC} / \mathrm{PM}_{10}$ ratio $<\sim 1.3$ were measured during the AD2_07 (31 March-1 April 2007), AD5_07 (29 December 2007), AD1_08 (12 February 2008), and AD2_08 (16-17 March 2008) periods, indicating the dominance of dust particles.

Low Ångström exponent of aerosol extinction between $340-550 \mathrm{~nm}, \alpha_{e}(340-550 \mathrm{~nm})$ was determined to be $<0.40$ during the Asian dust periods except AD03_07 period. It was found that Asian dust event occurred in spring frequently accompanies with anthropogenic pollutants from urban and industrial regions of eastern China as well as biomass burning. It is reported that the coagulation of EC onto the surface of dust particles reduced overall shortwave absorption by $-10 \%$ to $-40 \%$ (Chuang et al., 2003). Thus, Asian dust accompanying with anthropogenic pollutants can change total absorption by EC. Care should be needed in calculating the radiative forcing by the mixture of Asian dust and anthropogenic pollutant.

$b_{\text {scat }}, b_{\text {abs }}$, and SSA as well as spectral dependence of SSA during the Asian dust periods are plotted in Fig. 13 as a function of wavelength. Decreasing trend of $b_{\mathrm{abs}}$ was observed during Asian dust periods as wavelength increases. On the other hand, $b_{\text {scat }}$ during the Asian dust periods was invariant with wavelength except for the AD1_07 and AD3_07 periods, indicating the predominance of coarse mode particles. Slightly decreasing trend of $b_{\text {scat }}$ observed during the AD1_07 and AD3_07 periods can be explained by high spectral dependence of anthropogenic fine particles transported together with Asian dust particles.

It is shown that SSA of Asian dust particles increases with wavelength. Higher spectral dependence of SSA was observed in the short visible region $(370-520 \mathrm{~nm})$ than that in the long visible region $(590-950 \mathrm{~nm})$, which can be partially explained by additional absorption in short visible region by light absorbing dust particles (Fialho et al., 2005) and/or organic aerosols (Kirchstetter et al., 2004). After excluding the mixed cases of AD1_07, AD3_07 and AD4_07, it was found that SSA of Asian dust aerosol was relatively high in the range of 0.92-0.97 at $550 \mathrm{~nm}$ with strong spectral dependence. 
(a)

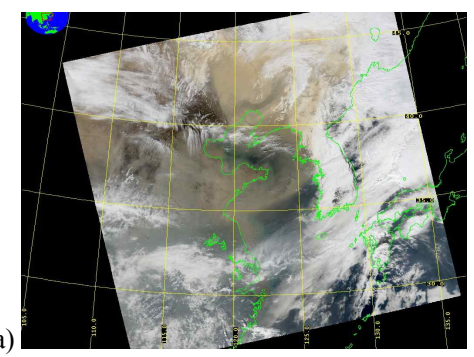

(b)

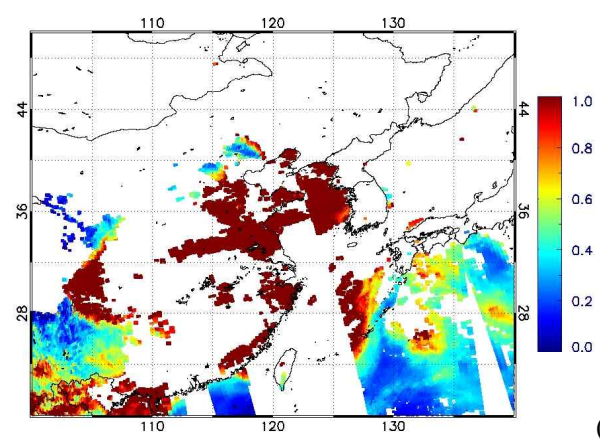

(c)

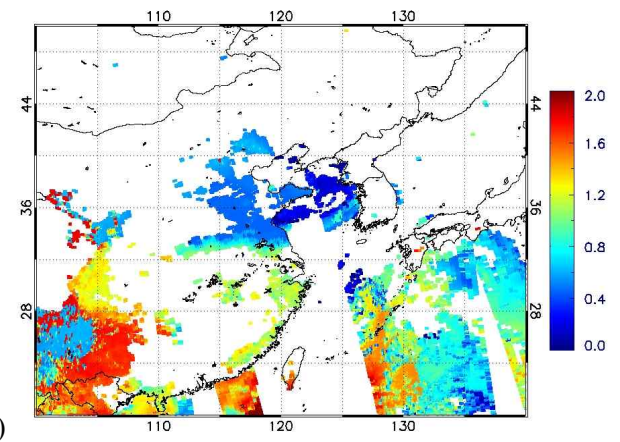

Fig. 11. (a) MODIS RGB image, (b) AOT, and (c) AOT Ångström exponent during the Asian dust event on 31 March 2007.
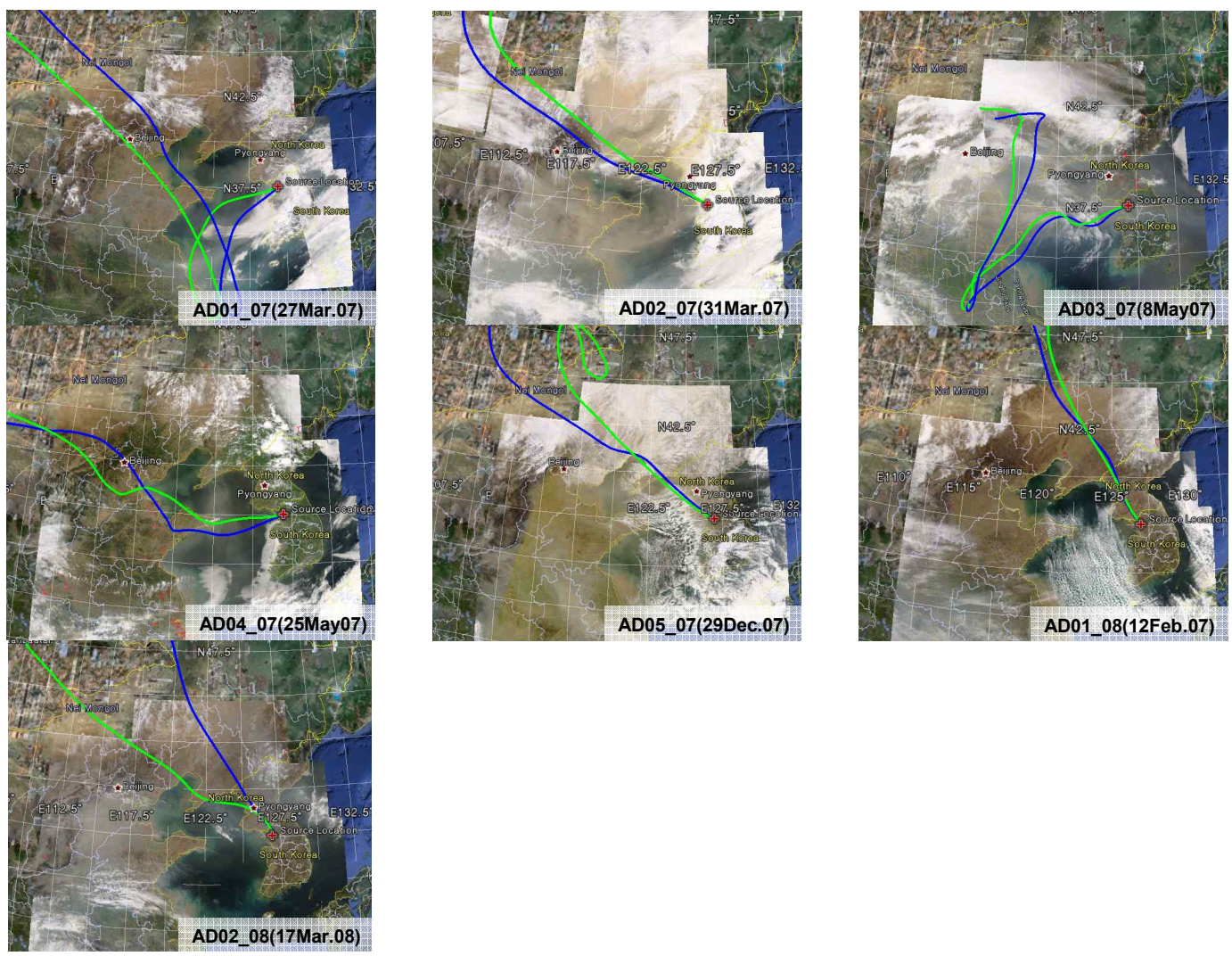

Fig. 12. MODIS RGB images and back-trajectories during the Asian dust periods arriving at the measurement site. Blue and yellowish green are back-trajectories arriving at 500 and $1000 \mathrm{~m}$ altitudes, respectively. 
Table 5. Summary of aerosol physical and optical properties measured during different long-range transport pollution (LTP) periods.

\begin{tabular}{|c|c|c|c|c|c|c|c|c|}
\hline Category & Period & $\mathrm{PM}_{10}\left(\mu \mathrm{gm}^{-3}\right)$ & $\mathrm{PM}_{2.5}\left(\mu \mathrm{gm}^{-3}\right)$ & $\mathrm{PM}_{2.5} / \mathrm{PM}_{10}(\%)$ & $\mathrm{BC} \mathrm{PM}_{10}(\%)$ & $\mathrm{RH}(\%)$ & $\alpha_{e(340-550 \mathrm{~nm})}$ & $\alpha_{e(550-1020 \mathrm{~nm})}$ \\
\hline LTP01_07 & 23-24 Jul 2007 & $176.9 \pm 40.7$ & $163.7 \pm 40.9$ & 92.1 & $4.0 \pm 1.0$ & $70.2 \pm 15.5$ & 0.99 & 1.38 \\
\hline LTP02_07 & 10-13 Sep 2007 & $125.4 \pm 27.2$ & $108.9 \pm 25.4$ & 86.7 & $6.1 \pm 1.4$ & $72.2 \pm 11.8$ & 1.20 & 1.47 \\
\hline LTP03_07 & $23-25$ Oct 2007 & $128.6 \pm 22.7$ & $112.3 \pm 20.9$ & 87.2 & $6.1 \pm 1.3$ & $71.7 \pm 14.9$ & 1.05 & 1.45 \\
\hline LTP04_07 & 6-9 Nov 2007 & $115.9 \pm 20.8$ & $94.9 \pm 18.7$ & 81.7 & $7.4 \pm 2.8$ & $54.3 \pm 15.4$ & 1.16 & 1.43 \\
\hline LTP01_08 & $6-8$ Feb 2008 & $152.0 \pm 24.6$ & $136.6 \pm 24.4$ & 89.7 & $6.5 \pm 1.5$ & $77.7 \pm 10.2$ & 0.85 & 0.96 \\
\hline LTP02_08 & 11-13 Mar 2008 & $122.4 \pm 11.3$ & $111.0 \pm 10.4$ & 90.7 & $5.0 \pm 0.7$ & $54.9 \pm 12.6$ & 1.00 & 1.40 \\
\hline
\end{tabular}

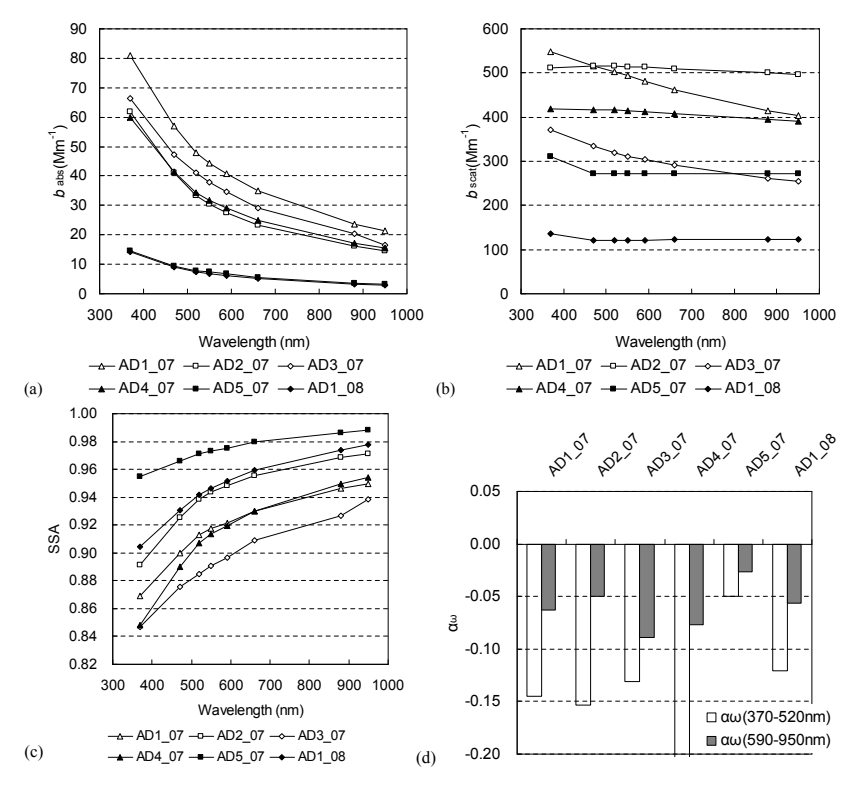

Fig. 13. (a) $b_{\text {abs }}$, (b) $b_{\text {scat }}$, and (c) SSA as a function of wavelength as well as (d) Ångström exponent $\left(\alpha_{\omega}\right)$ of SSA during the Asian dust periods.

\subsubsection{Long-range transport pollution aerosols}

MODIS RGB images and Hysplit air mass backward trajectories arriving at the measurement site during LTP periods are shown in Fig. 14. Blue and yellowish green lines represent backward trajectories arriving at 500 and $1000 \mathrm{~m}$ a.g.l. heights, respectively. During the LTP periods, most of air masses were originated from the industrial areas of eastern China (Shanghai to Beijng regions) and transported to the measurement site.

During the LTP02_07 (10-13 September 2007), LTP03_07 (23-25 October 2007), and LTP01_08 (6-8 February 2008) periods, MODIS RGB images clearly show the transport of anthropogenic aerosols from eastern China to downwind areas. Spatial distributions of AOT over northeast Asia during the LTP03_07 are shown in Fig. 15. On 22 October it is clearly seen that severe haze layer (AOT > 1.0) lingered over eastern China to Yellow sea and then transported to Korean peninsula. Outflow of severe haze plume is also seen on 23 October. In this case, the haze plume emitted from eastern China moved to south-east direction and then turned toward Korean peninsula, resulting in very high AOT over the measurement site on 24 October.

Observed aerosol physical and optical properties during the LTP periods are summarized in Table 5. Average $\mathrm{PM}_{10}$ during the LTP periods ranged from $75.7 \mu \mathrm{gm}^{-3}$

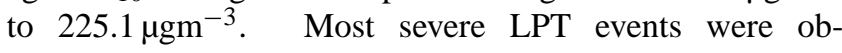
served during 23-24 July 2007 (LTP01_07) and 6-8 January 2008 (LTP01_08) with average $\mathrm{PM}_{10}$ concentrations of $176.9 \pm 40.7$ and $152.0 \pm 24.6 \mu \mathrm{gm}^{-3}$, respectively. Since most of haze events were anthropogenic origin, high $\mathrm{PM}_{2.5} / \mathrm{PM}_{10}$ ratios of $>0.87$ was observed during the LTP periods except for the LTP04_07 (6-9 Nov. 2007) period. Average $\mathrm{BC} / \mathrm{PM}_{10}$ and $\mathrm{BC} / \mathrm{PM}_{2.5}$ mass ratios were determined to be $5.7 \pm 2.0 \%$ (in the range of 3.6-7.4\%) and $6.7 \pm 2.6 \%$ (4.4-9.2\%), respectively, during the LTP periods. The average of $\mathrm{BC} / \mathrm{PM}_{2.5}$ ratio during the LTP periods is comparable to $6.9 \%$ observed at an urban site in Beijing, China (Jung et al., 2009a) and $\sim 7 \%$ at an urban site in Seoul, Korea, respectively (Kim et al., 2007a). High values of $\alpha_{e}(340-550 \mathrm{~nm})$ and $\alpha_{e}(550-1020 \mathrm{~nm})$ were obtained in the range of 0.85-1.20 (avg. 1.04) and 0.96-1.47 (avg. 1.35), respectively, which indicates the dominance of small particles in the LTP aerosols.

$b_{\text {scat }}, b_{\text {abs }}$, and SSA as well as spectral dependence of SSA during the LTP periods are shown in Fig. 16 as a function of wavelength. Decreasing trend of $b_{\text {scat }}$ and $b_{\text {abs }}$ with wavelength was observed during the LTP periods. Due to these decreasing trends of $b_{\text {scat }}$ and $b_{\text {abs }}$ with wavelength, SSA showed little spectral dependence during the LTP periods. High SSA was obtained to be $0.94-0.96$ at $550 \mathrm{~nm}$ during the LTP periods except the LTP04_07 period, which can be explained by relative increase of secondary aerosols such as sulfate, nitrate, and secondary organic aerosols during the pollution period at urban sites in Korea and China (Kim et al., 2007a; Jung et al., 2009a, b). Lower $\alpha_{w}$ was obtained during the LTP periods than the Asian dust periods. From the spectral dependence of SSA during the AD and LTP periods, it is suggested that wavelength independent SSA can be used in calculating short wave radiative forcing by anthropogenic pollution aerosols. However, spectral dependence of SSA 

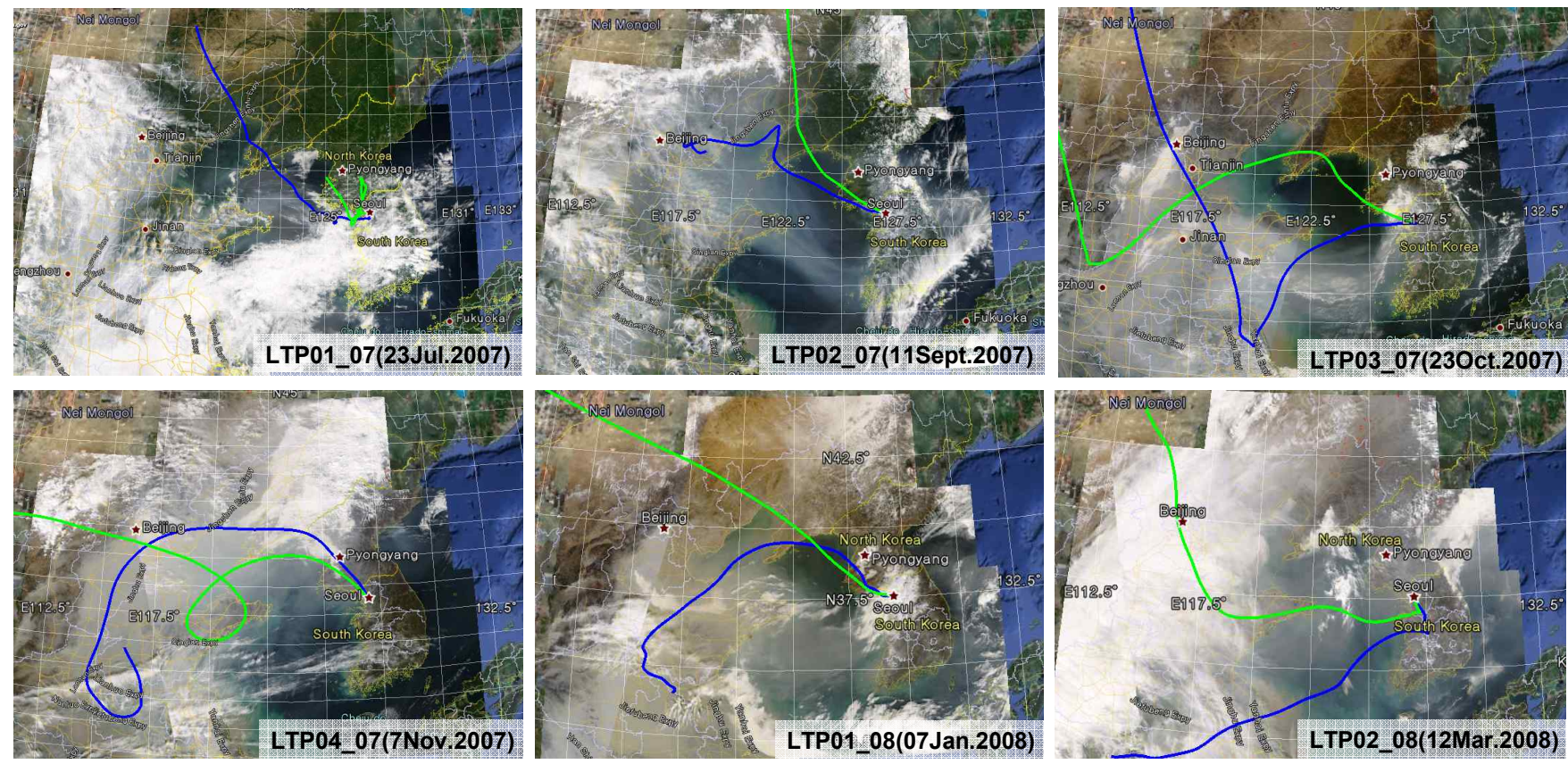

Fig. 14. MODIS RGB images and back-trajectories during the LTP periods. Blue and yellowish green are back-trajectories arriving at 500 and $1000 \mathrm{~m}$ altitudes, respectively.
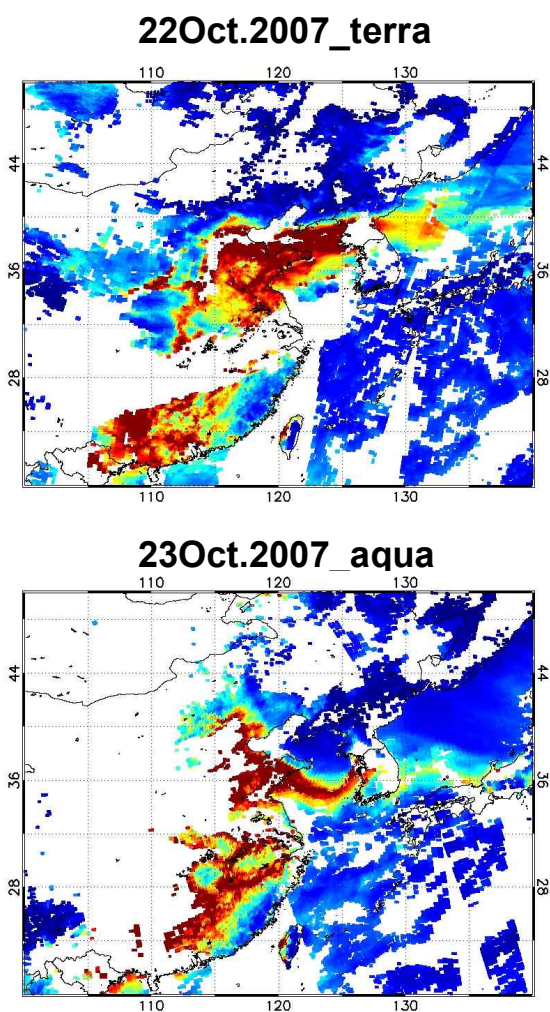

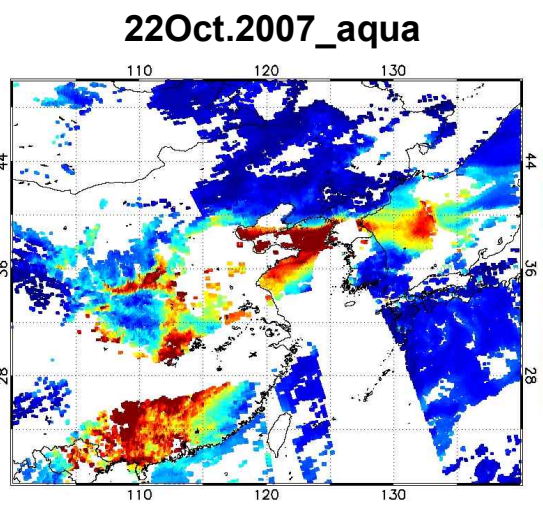

\section{0ct.2007_terra}

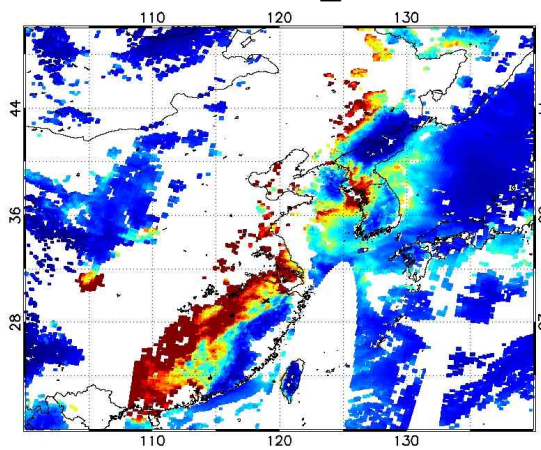

230ct.2007_terra

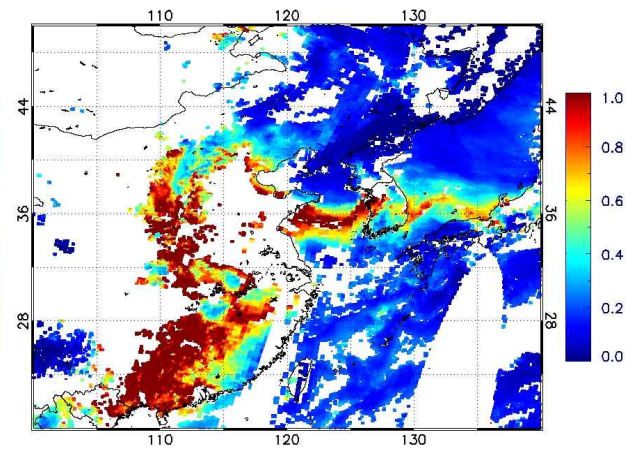

240ct.2007_aqua

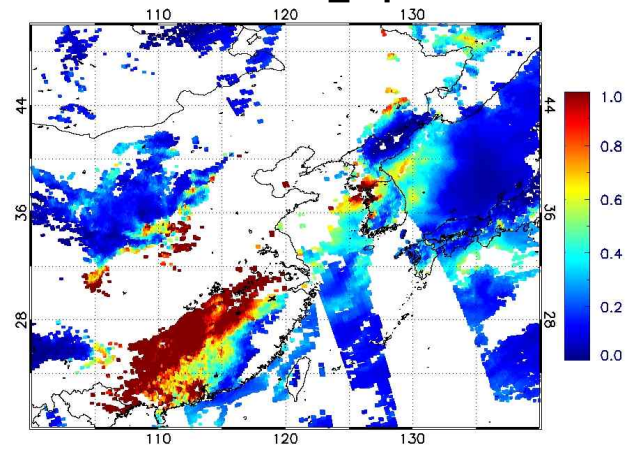

Fig. 15. Spatial distribution of AOT over Northeast Asia during the selected days of LRT period (22-24 October 2007). 

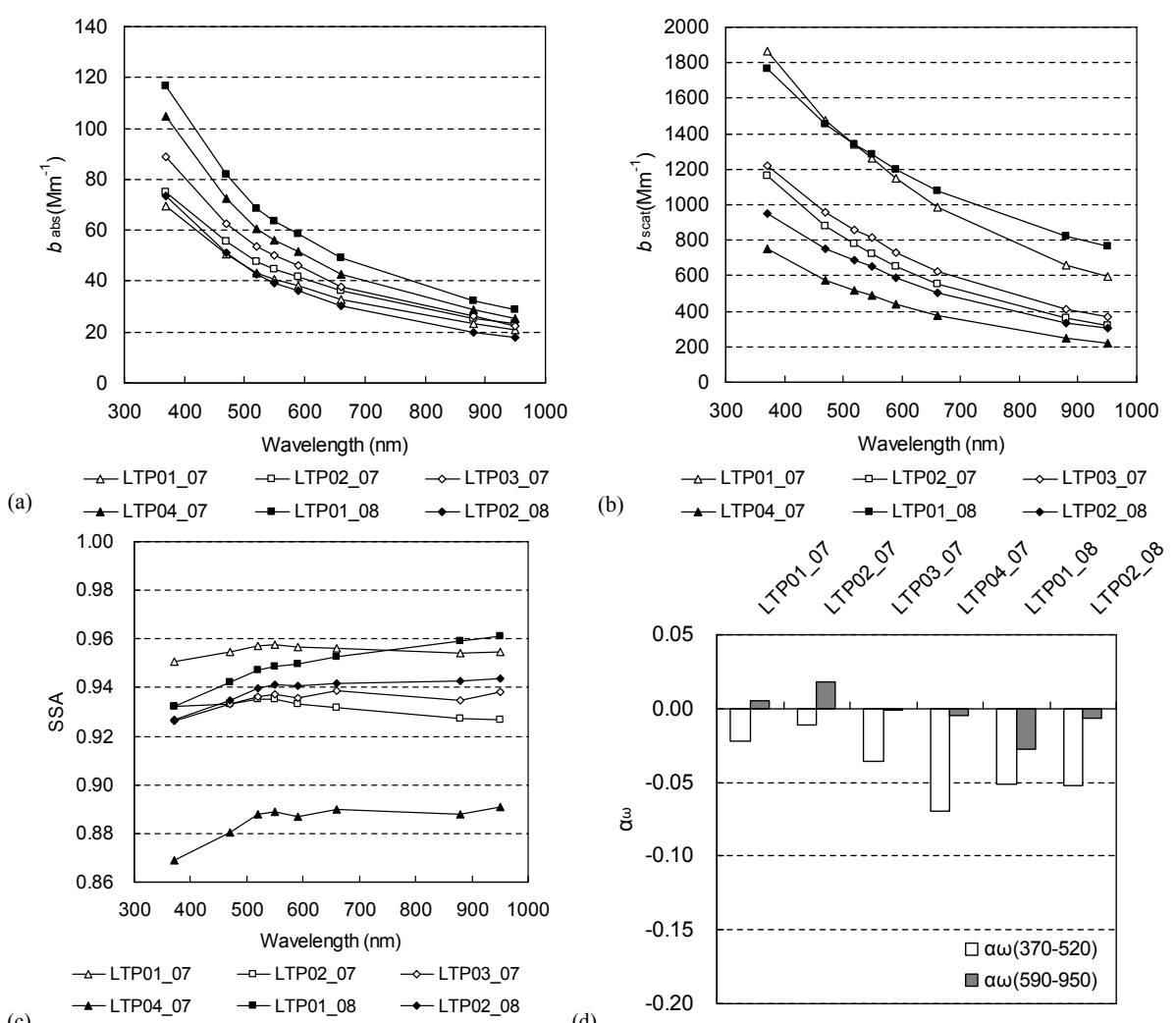

$\rightarrow-$ LTP01_07 $\rightarrow$ - L LTP02_07 $\rightarrow$ LTP03_07

(b) $\quad$-LTP04_07 $\rightarrow$ LTP01_08 $\rightarrow$ LTP02_08

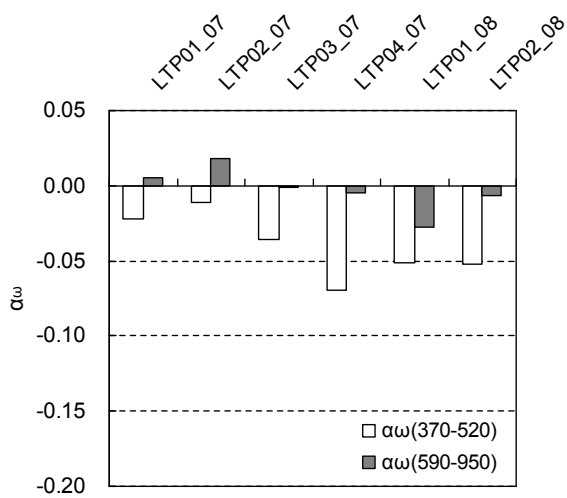

Fig. 16. (a) $b_{\text {abs }}$, (b) $b_{\text {scat }}$, and (c) SSA as a function of wavelength as well as (d) $\alpha_{\omega}$ during the LTP periods.
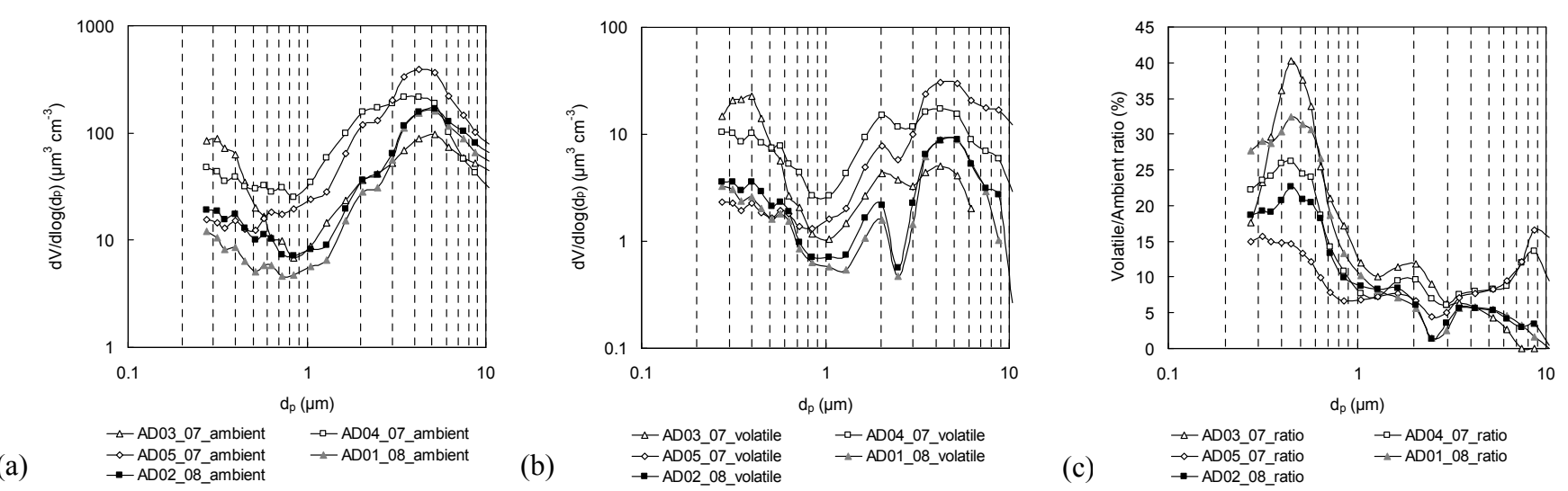

Fig. 17. Volume size distribution of (a) ambient, (b) volatile aerosol, and (c) volatile fraction to ambient aerosol during the Asian dust periods.

shown in Fig. 13d should be carefully considered for the calculation of the radiative forcing by dust particles, which can reduce uncertainties associated with aerosol radiative properties.

This study suggests that it is possible to classify haze types based on the physical and optical properties of aerosol. Asian dust event can be classified as low $\mathrm{PM}_{2.5} / \mathrm{PM}_{10}$ mass ra- tio of $<\sim 0.4, \mathrm{BC}_{\mathrm{PM}} 10$ ratio of $<\sim 1.3 \%$, and $\alpha_{e}(340-$ $550 \mathrm{~nm}$ ) of $<0.40$. However, LTP event can be classified as high $\mathrm{PM}_{2.5} / \mathrm{PM}_{10}$ mass ratio, $\mathrm{BC} / \mathrm{PM}_{10}$ ratio of $>3.6 \%$, and $\alpha_{e}(340-550 \mathrm{~nm})$ of $>0.85$. 

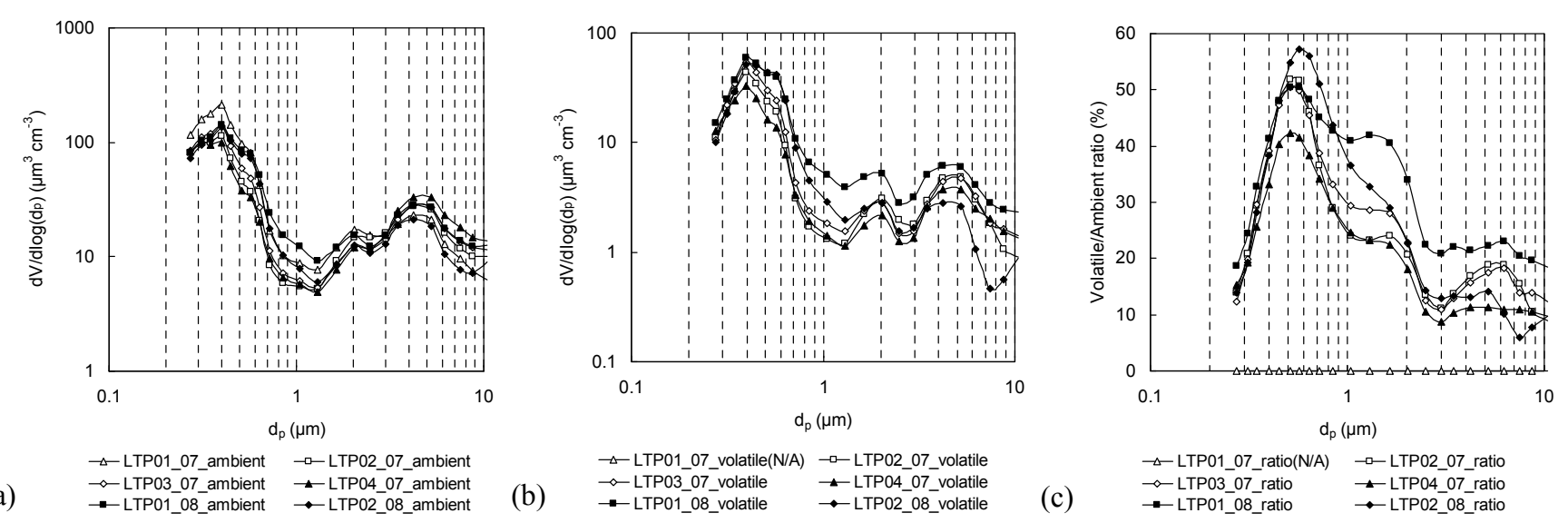

Fig. 18. Volume size distribution of (a) ambient, (b) volatile aerosol, and (c) volatile fraction to ambient aerosol during the LTP periods.

\subsection{Volume size distribution of long-range transport aerosols}

Log volume distributions of ambient and volatile aerosols during the AD and LTP periods are seen in Figs. 17-18. Volatile aerosols in this study represent the aerosols, which are volatilized under $110^{\circ} \mathrm{C}$. Tri-modal distributions with the predominance in coarse mode $(4-5 \mu \mathrm{m})$ were observed during the Asian dust periods. However, four mode distributions peaked at $0.4,0.6,2$, and $4-5 \mu \mathrm{m}$ corresponding to the condensation mode, droplet mode-1, droplet mode-2, and coarse mode, respectively, were observed during the LTP periods. Interestingly, the droplet mode- 2 was clearly observed during the LTP and the AD periods.

When air mass was originated from China continent, trimodal mass distribution with additional droplet mode peaked at $1.0-1.8 \mu \mathrm{m}$ was observed at downwind site in northeast China (Liu et al., 2008). Guo et al. (2010) also observed additional droplet modes peaked at 0.8 and $1.4 \mu \mathrm{m}$ based on size-segregate aerosol measurement and PMF peak separation. From the chemical analyses, they found that the additional droplet modes were mainly consisted of sulfate, nitrate, and ammonium formed by in-cloud or aerosol droplet process. Guo et al. (2010) argued that the droplet mode-2 was mainly from regional transport. As a result, it can be estimated that the droplet mode- 2 during the AD and LTP periods is probably due to secondary aerosols formed by in-cloud and/or aerosol droplet process during the long-transport.

Condensation mode is the result of growth of ultrafine particles by coagulation and vapor condensation while coarse mode is mainly from nitrate, sea salt, and soil (Liu et al., 2008; Guo et al., 2010). However, droplet modes are from particle growth by in-cloud or aerosol droplet process. Volume distributions of volatile aerosols during the LTP periods are similar to those of ambient aerosols. However, volatile fraction to ambient aerosols showed different volume size distributions with the predominance in the droplet mode-1, followed by the droplet mode-2. It is well known that most of ammonium nitrate is volatilized under $110^{\circ} \mathrm{C}$ but only certain fractions of ammonium sulfate and organic aerosols are volatilized. Thus, it can be estimated that higher fractions of the droplet mode- 1 and the droplet mode- 2 were mainly consisted of ammonium nitrate and/or high volatile organic aerosols rather than sulfate related aerosols.

\section{Conclusion}

Based on the aerosol optical and physical properties measured for one year at an urban site $\left(37.57^{\circ} \mathrm{N}, 126.94^{\circ} \mathrm{E}\right)$ in Seoul, Korea, characteristics of aerosol spectral optical properties including single scattering albedo (SSA) have been investigated in this study. From the spectral dependence of $b_{\text {scat }}$ under relatively dry and humid conditions, increases of SSA and particle size were clearly observed through water uptake under humid condition-especially in summer. It was found that aerosol water content is one of important parameter to determine $b_{\text {scat }}$ and SSA as well as particle size during humid summer period. It was found that on average SSA decreased by $7 \%$ due to contribution by aerosol water content. Mass fraction of sulfate and nitrate to total mass dominantly increased during the pollution event periods in the Megacities of Korea (Kim et al., 2007a) and China (Jung et al., 2009a, b). Thus, high SSA during the LTP periods was mainly attributed to the increased contribution of light scattering by secondary aerosols. From the calibration study between thermally measured EC and optically measured $\mathrm{BC}$, clear seasonal variation of mass attenuation efficiency $\left(\sigma_{\mathrm{ATN}}=b_{\mathrm{ATN}} / E C\right)$ was observed with the maximum value in summer. High $\sigma_{\mathrm{ATN}}$ in summer can be attributed to the enhancement of light attenuation capacity of EC through the change of its mixing state. Therefore, it is recommended that a proper seasonal $\sigma_{\mathrm{ATN}}$ value be used for filter based BC measurement.

From MODIS satellite AOT and Hysplit air mass backward trajectory analyses as well as chemical analysis, it was 
found that Asian dust event occurred in spring frequently accompanies with anthropogenic pollutants emitted from industrial regions of eastern China. Increasing trend of SSA with wavelength was observed during the Asian dust period while little spectral dependence of SSA was observed except below $500 \mathrm{~nm}$ during long-range transport pollution (LTP) periods. Although there still exist large uncertainties in radiative transfer calculations for determining radiative forcing of atmospheric aerosol, few studies have been done regarding spectral optical properties of urban aerosol and Asian dust particle in Northeast Asia based on long-term continuous measurement data. Thus, aerosol spectral optical properties obtained in this study can provide useful information for quantifying aerosol's climate change effects.

Acknowledgements. This research was supported by the National Research Foundation of Korea (NRF) grant funded by the Korea government (MEST) (No. R17-2010-0000773). The authors thank the NOAA Air Resources Laboratory (ARL) for the provision of the HYSPLIT transport and dispersion model and/or READY website (http://www.arl.noaa.gov/ready.php) used in this publication. The authors also thank the NASA-US for making available the Collection 005 Level-2 MODIS data.

Edited by: C. H. Song

\section{References}

Andreae, M. O., Schmid, O., Yang, H., Chand, D., Yu, J. Z., Zeng, L., and Zhang, Y.: Optical properties and chemical composition of the atmospheric aerosol in urban Guangzhou, China, Atmos. Environ., 42, 6335-6350, 2008.

Arnott, W. P., Hamasha, K., Moosmüller, H., Sheridan, P. J., and Ogren, J. A.: Towards aerosol light-absorption measurements with a 7-wavelength aethalometer: Evaluation with a photoacoustic instrument and 3-wavelength nephelometer, Aerosol Sci. Technol., 39, 17-29, 2005.

Badarinath, K. V. S., Kharol, S. K., and Sharma, A. R.: Longrange transport of aerosols from agriculture crop residue burning in Indo-Gangetic Plains-A study using LIDAR, ground measurements and satellite data, J. Atmos. and Solar-Terr. Phys., 71, 112-120, 2009.

Ballach, J., Hitzenberger, R., Schultz, E., and Jaeschke, W.: Development of an improved optical transmission technique for black carbon (BC) analysis, Atmos. Environ., 35, 2089-2100, 2001.

Balis, D. S., Amiridis, V., Zerefos, C., Gerasopoulos, E., Andreae, M., Zanis, P., Kazantzidis, A., Kazadzi, S., and Papayannis, A.: Raman lidar and sunphotometric measurements of aerosol optical properties over Thessaloniki, Greece during a biomass burning episode, Atmos. Environ., 37 (32), 4529-4538, 2003.

Bergin, M. H., Cass, G. R., Xu, J., Fang, C., Zeng, L. M., Yu, T., Salmon, L. G., Kiang, C. S., Tang, X. Y., Zhang, Y. H., and Chameides, W. L.: Aerosol radiative, physica, and chemical properties in Beijing during June, 1999, J. Geophys. Res., 106(D16), 17969-17980, 2001.

Birch, M. E. and Cary, R. A.: Elemental Carbon-Based Method for Monitoring Occupational Exposures to Particulate Diesel Exhaust, Aerosol Sci. Technol., 25, 221-241, 1996.
Bond, T. C.: Spectral dependence of visible light absorption by carbonaceous particles emitted from coal combustion, Geophys. Res. Lett., 28, 4075-4078, 2001.

Chuang, P. Y., Duvall, R. M., Bea, M. S., Jefferson, A., Schauer, J. J., Yang, H., Yu, J. Z., and Kim, J.: Observations of elemental carbon and absorption during ACE-Asia and implications for aerosol radiative properties and climate forcing, J. Geophy. Res., 108, 8634, doi:10.1029/2002JD003254, 2003.

Draxler, R. R. and Rolph, G. D.: HYSPLIT (HYbrid Single-Particle Lagrangian Integrated Trajectory) Model access via NOAA ARL READY Website (http://www.arl.noaa.gov/ HYSPLIT.php), NOAA Air Resources Laboratory, Silver Spring, MD, USA, 2003.

Dubovik, O., Holben, B., Eck, T. F., Smirnov, A., Kaufman, Y. J., King, M. D., Tanre, D., and Slutsker, I.: Variability of absorption and optical properties of key aerosol types observed in worldwide locations, J. Atmos. Sci., 59, 590-608, 2002.

Fialho, P., Hansen, A. D. A., and Honrath, R. E.: Absorption coefficients by aerosols in remote areas: a new approach to decouple dust and black carbon absorption coefficients using sevenwavelength Aethalometer data, J. Aerosol Sci., 36, 267-282, 2005.

Forster, P., Ramaswamy, V., Artaxo, P., Berntsen, T., R. Betts, Fahey, D.W., Haywood, J., Lean, J., Lowe, D.C., Myhre, G., Nganga, J., Prinn, R., Raga, G., Schulz, M. and Van Dorland, R.: Changes in Atmospheric Constituents and in Radiative Forcing. In: Climate Change 2007: The Physical Science Basis. Contribution of Working Group I to the Fourth Assessment Report of the Intergovernmental Panel on Climate Change edited by:Solomon, S., Qin, D., Manning, M., Chen, Z., Marquis, M., Averyt, K. B., Tignor, M., and Miller, H. L., Cambridge University Press, Cambridge, UK and New York, NY, USA, 2007.

Grimm, H.: Field Experience of Portable Aerosol Spectrometer For Simultaneous Monitoring of $\mathrm{PM}_{10}, \mathrm{PM}_{2.5}$ and $\mathrm{PM}_{1.0}$, AAAR Conference, Atlanta, USA, 2002.

Grim, H. and Eatough, D. J.: Aerosol Measurement: The Use of Optical Light Scattering for the Determination of Particulate Size Distribution, and Particulate Mass, Including the Semi-Volatile Fraction, Air Waste Manage. Assoc., 59, 101-107, 2009.

Guo, S., Hu, M., Wang, Z. B., Slanina, J., and Zhao, Y. L.: Sizeresolved aerosol water-soluble ionic compositions in the summer of Beijing: implication of regional secondary formation, Atmos. Chem. Phys., 10, 947-959, 2010, http://www.atmos-chem-phys.net/10/947/2010/.

Hansen, A. D. A.: The Aethalometer, manual, Berkeley, California, USA, Magee Scientific, 2005.

Heintzenberg, J., Charlson, R. J., Clarke, A. D., Liousse, C., Ramaswamy, V., Shine, K. P., Wendisch, M., and Helas, G.: Measurements and modeling of aerosol single-scattering albedo: Progress, problems and prospects, Contrib. Atmos. Phys., 70, 249-263, 1997.

Höller, R., Ito, K., Tohno, S., and Kasahara, M.: Wavelengthdependent aerosol single-scattering albedo: Measurements and model calculations for a coastal site near the Sea of Japan during ACE-Asia, J. Geophys. Res., 108(D23), 8648, doi:10.1029/2002JD003250, 2003.

Jacob, D. J., Logan, J. A., and Murti, P. P.: Effect of rising Asian emissions on surface ozone in the United States, Geophys. Res. Lett., 26, 2175-2178, 1999. 
Jacobson, M. Z.: Strong Radiative Heating due to the Mixing State of Black Carbon in Atmospheric Aerosols, Nature, 409(6821), 672-695, 2001

Jeong, C.-H., Hopke, P. K., Kim, E., and Lee, D.-W.: The comparison between thermal-optical transmittance elemental carbon and Aethalometer black carbon measured at multiple monitoring sites, Atmos. Environ., 38, 5193-5204, 2004.

Jung, J. S., Lee, H. L., Kim, Y. J., Liu, X., Liu, X., Zhang, Y., $\mathrm{Hu}$, M., and Sugimoto, M.: Optical Properties of Atmospheric Aerosols Obtained by In-situ and Remote Measurements during 2006 CAREBEIJING Campaign, J. Geophys. Res., 114, D00G02, doi:10.1029/2008JD010337, 2009a.

Jung, J. S., Lee, H.L., Kim, Y.J., Liu, X., Zhang, Y., Gu, J., and Fan, S.: Aerosol chemistry and the effect of aerosol water content on visibility impairment and radiative forcing in Guangzhou during the 2006 Pearl River Delta campaign, J. Environ. Manage., 90, 3231-3244, 2009b.

Kim, H.-S., Huh, J- B, Hopke, P. K., Holsen, T. M., and Yi, S.-M.: Characteristics of the major chemical constituents of $\mathrm{PM}_{2.5}$ and smog events in Seoul, Korea in 2003 and 2004, Atmos. Environ., 41, 6762-6770, 2007a.

Kim, K. W., Kim, Y. J., and Oh, S. J.: Visibility Impairment during Yellow Sand Periods in the Urban Atmosphere of Kwangju, Korea, Atmos. Environ., 35, 5157-5167, 2001.

Kim, S.-W., Yoon, S.-C., Kim, J., and Kim, S.-Y.: Seasonal and monthly variations of columnar aerosol optical properties over East Asia determined from multi-year MODIS, LIDAR, and AERONET Sun/sky radiometer measurements, Atmos. Environ., 41, 1634-1651, 2007b.

Kim, Y. J., Kim, M. J., Lee, K. H., and Park, S. S.: Investigation of carbon pollution episodes using semi-continuous instrument in Incheon, Korea, Atmos. Environ., 40(22), 4064-4075, 2006.

Kim, J. Y.: Transport routes and source regions of Asian dust observed in Korea during the past 40 years (1965-2004), Atmos. Environ., 42, 4778-4789, 2008.

Kirchstetter, T. W., Novakov, T., and Hobbs, P. V.: Evidence that the spectral dependence of light absorption by aerosols is affected by organic carbon, J. Geophys. Res., 109, D21208, doi:10.1029/2004JD004999, 2004.

Kondo, Y., Sahu, L., Kuwata, M., Miyazaki, Y., Takegawa, N., Moteki, N., Imaru, J., Han, S., Nakayama, T., Kim Oanh, N.T., Min, H., Kim, Y. J., and Kita, K.: Stabilization of the mass absorption cross section of black carbon for filter-based absorption photometry by the use of a heated inlet, Aerosol Sci. Technol., 43(8), 741-756, 2009.

Kopp, C., Petzold, A., and Niessner, R.: Investigation of the specific attenuation cross-section of aerosols deposited on fiber filters with a polar photometer to determine black carbon, J. Aerosol Sci., 30, 1153-1163, 1999.

Lee, K. H., Kim, J. E., Kim, Y. J., Kim, J., and von HoyningenHuene, W.: Impact of the Smoke Aerosol from Russian Forest Fires on the Atmospheric Environment over Korea during May 2003, Atmos. Environ., 39(1), 85-99, 2005.

Lee, K. H., Kim, Y. J., von Hoyningen-Huene, W., and Burrow, J. P.: Spatio-temporal variability of satellite-derived aerosol optical thickness over Northeast Asia in 2004, Atmos. Environ., 41, 3959-3973, 2007.

Levy, R. C., Remer, L. A., and Dubovik, O.: Global aerosol optical properties and application 15 to Moderate Resolution Imaging
Spectroradiometer aerosol retrieval over land, J. Geophys. Res., 112(D13), D13210, doi:10.1029/2006JD007815, 2007a.

Levy, R. C., Remer, L. A., Mattoo, S., Vermote, E. F., and Kaufman, Y. J.: Second-generation operational algorithm: retrieval of aerosol properties over land from inversion of moderate resolution imaging spectroradiometer spectral reflectance, J. Geophys. Res., 112(D13), D13211, doi:10.1029/2006JD007811, 2007b.

Li, C., Marufu, L. T., Dickerson, R. R., Li, Z., Wen, T., Wang, Y., Wang, P., Chen, H., and Stehr, J. W.: In situ measurements of trace gases and aerosol optical properties at a rural site in northern China during East Asian Study of Tropospheric Aerosols: An International Regional Experiment 2005, J. Geophys. Res., 112, D22S04, doi:10.1029/2006JD007592, 2007.

Liu, S., Hu, M., Slanina, S., He, L.-Y., Niu, Y.-W., Bruegemann, E., Gnauk, T., and Herrmann, H.: Size distribution and source analysis of ionic compositions of aerosols in polluted periods at Xinken in Pearl River Delta (PRD) of China, Amos. Environ., 42, 6284-6295, 2008.

Nakajima T., Tonna, G., Rao, R., Boi, P., Kaufman, Y., and Holben, B.: Use of sky brightness measurements from ground for remote sensing of particulate poly dispersions, Appl. Opt., 35(15), 2672-2686, 1996.

Naoe, H. and Okada, K.: Mixing properties of submicrometer aerosol particles in the urban atmosphere-with regard to soot particles, Atmos. Environ., 35, 5765-5772, 2001.

Nessler, R., Weingartner, E., and Baltensperger, U.: Effect of humidity on aerosol light absorption and its implications for extinction and the single scattering albedo illustrated for a site in the lower free troposphere, J. Aerosol Sci., 36, 958-972, 2005.

Optec: Model NGN-2 Open-Air Integrating Nepheolometer: Technical Manual for Theory of Operation and Operating Procedures, OPTEC Inc., 199 Smith Street Lowell, MI 49331, USA, 1993.

Park, S. S., Kim, Y. J., and Kang, C. H.: Atmospheric polycyclic aromatic hydrocarbons in Seoul, Korea, Atmos. Environ., 36, 2917-2924, 2002.

Park, S. U. and Kim, J. W.: Aerosol size distributions observed at the Seoul National University campus in Korea during the Asian dust and non-Asian dust periods, Atmos. Environ., 40, 1722 1730, 2006.

Petzold, A., Kopp, C., and Niessner, R.: The dependence of the specific attenuation cross section on black carbon mass fraction and particle size, Atmos. Environ., 31, 661-672, 1997.

Polidori, A., Turpin, B. J., Lim, H.-J., Cabada, J. C., Subramanian, R., Pandis, S. N., and Robinson, A. L.: Local and Regional Secondary Organic Aerosol: Insights from a Year of Semi-Continuous Carbon Measurements at Pittsburgh, Aerosol Sci. Technol., 40, 861-872, 2006.

Pósfai, M., Anderson, J., Buseck, P., and Sievering, H.: Soot and sulfate aerosol particles in the remote marine troposphere, J. Geophys. Res., 104(D17), 21685-21693, 1999.

Redemann, J., Russell, P. B., and Hamill, P.: Dependence of aerosol light absorption and single-scattering albedo on ambient relative humidity for sulfate aerosols with black carbon cores, J. Geophy. Res., 106(D21), 27485-27495, 2001.

Rolph, G.D.: Real-time Environmental Applications and Display sYstem (READY) Website, http://www.arl.noaa.gov/ready.php, NOAA Air Resources Laboratory, Silver Spring, MD, USA, 2003.

Ryu, S. Y., Kwon, B. G., Kim, Y. J., Kim, H. H., and Chun, K. 
J.: Characteristics of biomass burning aerosol and its impact on regional air quality in the summer of 2003 at Gwangju, Korea, Atmos. Res., 86, 362-373, 2006.

Schmid, O, Artaxo, P., Arnott, W. P., Chand, D., Gatti, L. V., Frank, G. P., Hoffer, A., Schnaiter, M., and Andreae, M. O.: Spectral light absorption by ambient aerosols influenced by biomass burning in the Amazon Basin. I: Comparison and field calibration of absorption measurement techniques, Atmos. Chem. Phys., 6, 3443-3462, 2006,

http://www.atmos-chem-phys.net/6/3443/2006/.

Snyder, D. C. and Schauer, J. J.: An inter-comparison of two black carbon aerosol instruments and a semi-continuous elemental carbon instrument in the urban environment, Aerosol Sci. Technol., 41, 463-474, 2007.
Weingartner, E., Saathoff, H., Schnaiter, M., Streit, N., Bitnar, B., and Baltensperger, U.: Absorption of light by soot particles: determination of the absorption coefficient by means of aethalometers, J. Aerosol Sci., 34, 1445-1463, 2003. 